\title{
1 \\ Archaeological perspectives on conflict and warfare in Australia and the Pacific
}

\author{
Geoffrey Clark and Mirani Litster
}

\begin{abstract}
Johnson ... laughed much at Lord Kames's opinion that war was a good thing occasionally, as so much valour and virtue were exhibited in it. A fire, says Johnson, might as well be thought a good thing: there is the bravery and address of the firemen employed in extinguishing it; there is much humanity exerted in saving the lives and properties of the poor sufferers; yet, says, he, after all this who can say fire is a good thing? (Hill and Powell 1934:393 n2)
\end{abstract}

\section{Introduction}

The overarching aim in producing an edited volume about conflict and warfare is to better understand the place of coercion and force in the Australia and Pacific region, how the region's populations were transformed through violence associated with contact, colonialism and globalisation, and the manner in which the legacies of past conflict have been communicated and received. To be sure, violence and conflict are not the only problems human societies face, but they are notorious for their devastating impact on social formations, natural environments and economic systems, and frequently mark significant historical inflection points in the development of nation-states and global systems. For these reasons, major thinkers have long theorised on the causes and purposes of warfare, especially in relation to the state, and whether conflict is innate to human behaviour and society. Our region has the clear potential to contribute more significantly to scholarship concerning the development and role of violence in hunter-gatherer communities over millennia, the evolution of conflict in circumscribed and 'open' island societies, and links frequently drawn between violence and warfare, and culture contact and colonialism. The latter was accompanied by the European introduction of new diseases, technologies and weaponry that, along with intrusive ideologies, had profound impacts on indigenous populations. Responses to intrusion and invasion often involved counter-responses: resistance, violence and warfare. These conflicts are important to remember and study (e.g. Connor 2002; Reynolds 1981; Smith 2000), as the acknowledgement of such events plays an important role in community and national dialogues that underpin reconciliation and truth-telling. Given the often sensitive nature of past events involving death and violence, it is essential that researchers responsibly investigate the history of past conflict. 
Remembrance of past violence has been constructive in informing public discourse recently in the 'Colonial frontier massacres in Australia, 1788-1930' project at the University of Newcastle, which brings together a large, dispersed set of historical records on conflicts and massacres in Australia since the establishment of a British colony in 1788 CE (see Ryan 2010). Other events include the 250th anniversary in 2020 CE of the Endeavour's arrival in Australia and the Pacific, which has stimulated debate about the negative effects of colonialism, from contact-era violence on the 'beach' to the subsequent dispossession of indigenous peoples of their land and culture. The entangled and complicated history of colonial campaigns is illustrated by the New Zealand Wars (Prickett 2016), in which sections of a Maori tribe (iwi) sometimes fought with British and colonial forces against other tribal groups, and other Pacific colonial conflicts where indigenous people were pitted against other Pacific Islanders, as in Vanuatu and Fiji (Bedford this volume; Douglas 1980; Nicole 2010). Similarly, in Australia and New Guinea, indigenous people were employed in 'pacification' to extend settler (Ryan 2010) and colonial government control—as with the Native Mounted Police in Queensland and the New Guinea Police Force (Burke and Wallis 2019; Kituai 1988; Wallis et al. 2017).

Archaeological investigation of places marked by violence such as Ruapekapeka Pā in northern New Zealand, where both European and Maori combatants died during significant military operations, has contributed to a national day of remembrance (Ra Maumahara) to acknowledge that while colonial settlement played a significant role in modern nation-building, so did intrusion, conflict and trauma. Even the arrival of Christian missionaries could lead to conflict (Howard and Kjellgren 1994) and 'Holy Wars' between the converted and those who maintained traditional beliefs (Cummins 1977), particularly in the Marianas, where Spanish colonisation in $1668 \mathrm{CE}$, primarily for religious conversion, led to significant outbreaks of warfare and violence (Burney 1813:274-315; Dixon et al. this volume). These examples reinforce a view that colonial expansion involved coercion, violence and punishment to emplace new economic, religious and power structures on both indigenous people and marginalised groups such as indentured workers, convicts and non-European migrants (Daly 2012; Evans and Thorpe 1992; Gunson 1969; Schamberger 2017). It seems likely that many conflict sites associated with marginalised groups will benefit from archaeological study and become foci for community memory and national recollection (Bedford this volume; Gilchrist 2003; Ouzman et al. this volume).

Much of the material evidence for past violence and warfare, even in the historical period, is ambiguous in revealing the particular type of conflict, the identity of the participants and the motivation and impetus for aggression. Developing accurate long-term records of conflict-an area where archaeological data and interpretation has a crucial role-requires new techniques and consideration of a broad range of site types such as buffer zones, refuges and observation/ lookouts (Grguric this volume, 2008; Smith 2000). Although inter-group aggression usually occurred on land, there are instances of marine conflict in the Pacific Islands, including the use of 'naval' vessels and large numbers of combatants. In Palau, the paramount chief of Koror in 1783 CE mobilised a war flotilla of more than 300 canoes (Keate 1788); a Tahitian fleet of 330 large and small war canoes was observed by James Cook; and the leader of the island of Hawai $i$, Kalaniopu'u, in $1779 \mathrm{CE}$ sailed with 150 large double canoes carrying more than 5000 men in a military expedition against the island of Maui (Clark 2017; Pang 2003:133). Aboriginal warriors used bark canoes (nawi) to launch raids to defend lands and waterways against British encroachment (Gapps 2018), as Edward Eyre (1984:153) recorded when moving cattle through the lands of the Yirawirung:

from the moment there was the least streak of dawn the canoes kept plying across the lagoon loaded with men, and by the time it was daylight we had them all ranged opposite against to us again with arms in their hand. 
Coasts and waterways are natural corridors for human movement and exploration and are locations where boundary maintenance and disputes over territory and resources are likely to occur (Pardoe 2014). Ocean and freshwater conflict locations will often be difficult to investigate archaeologically, although there are rare sites with evidence for indigenous conflict, including on Chuuk, in Micronesia, where large numbers of sling stones are recorded underwater (Brooks 1981:31). European ships were also sites of early violence, and the investigation of vessel remains and remains of shore camps hold substantial information about contact-era violence, as in Palau (Antelope, wrecked 1783 CE; Clark and de Biran 2010), Vanikoro (Boussole and Astrolabe, 1788 CE; Hitchcock 2017; Stanbury and Green 2004) and Tonga (Port au Prince, 1806 CE; Martin 1991). Religious and ceremonial sites are another under-studied source of information about the role of belief systems and ritual in conflict and warfare (Loeb 1926), and include war temples, shrines and elite burial structures (e.g. Kolb 2006; Sheppard et al. 2000).

In addition to consideration of a wider range of site types and a focus on conflict landscapes (e.g. Parton et al. 2018), research on violence in the past will benefit from ongoing critical analysis of traditional datasets such as textual and depictive records, human remains and studies of material culture connected with violence. In the Dynamic Figure rock art tradition of northern Australia, for example, there are scenes interpreted as showing fighting by small groups along with 'tumbling' figures perhaps indicative of trance and visions (Chippindale et al. 2000).

The problematic and equivocal identification of ancient conflict is particularly acute, not just in our region, but in the world (e.g. Cork 2005; Keeley et al. 2007; Kyle et al. 2009; Lipo et al. 2016; O’Driscoll 2017; Taçon and Chippindale 1994). In this regard, Australia and the Pacific are an important but still under-studied region for examining and refining records of conflict and warfare using archaeological approaches and allied disciplines (e.g. Litster and Wallis 2011). Although the two areas are usually held to be separate in archaeology, there were times when people, their genes and their cultural traits crossed traditional geographic enclaves. Dumont d'Urville's rightly maligned geocultural zone of 'Melanesia' (Tcherkézoff 2003), in particular, has been a sociocultural 'hinge zone' between Aboriginal Australia and the remote islands of Oceania, in addition, of course, to the peoples and cultures of island Asia (Ambrose 1988; Wesley et al. 2014; Wright et al. 2013). The latter area is the subject of a recent Terra Australis volume investigating the origins and purpose of forts in Wallacea that are likely to have developed, at least in part, in response to incipient globalisation heralded by economic and political expansions made by Chinese, Portuguese, Dutch and Muslim interests (O'Connor et al. 2020). In western New Guinea, fortified settlements (kotalotem) likely date to the seventeenth-nineteenth centuries $\mathrm{CE}$ and are similarly related to external trade and migration, although some may date older (Wright et al. 2013:56, 65).

An example of regional boundary crossing and cultural connections involving violence is the Waiat ritual in the Torres Strait, which has origins in west New Guinea and links to Cape York: it culminated in an annual inter-island ceremony that traditionally involved the sacrifice of captured people from New Guinea (Haddon 1928:135). Similarly, there were maritime voyages involving raiding and slavery from the Polynesian outlier of Taumako into Melanesia in the early seventeenth century (Amherst and Thomson 1901), along with traditional evidence for Tongan voyaging involving conflict and colony emplacement in several parts of Oceania (e.g. Ella 1899; Feinberg 1998; Gifford 1929).

Episodic and fluctuating connections — both terrestrial and maritime- that penetrated orthodox cultural regions were conduits through which knowledge about non-local people and societies moved, including the status of distant political systems, their cultural norms and information about trade items/valuables. The opportunity presented by these connections (e.g. Luders 1996; McBryde 1978; McNiven 1998; Mitchell 2000) for raiding, conflict and warfare among 
indigenous societies, sometimes over significant distances, is in some respects paralleled by the European exploration and contact phase in Australia and Oceania, when long-distance voyaging, culture contact and violence were virtually synonymous (Clark 2017; Orchiston and Horrocks 1975; Pearson 1970).

There are many types of contemporary violence, conflict and warfare (e.g. cyber, culture, drone, information, generational, chemical, psychological), and in antiquity there were several kinds of behaviour that materialised 'violence', from damage to statues and monuments that symbolised the political and belief systems of elites, to the destruction of material culture (Walter et al. 2004:150) and human remains (Barber 2012; McNiven 2018), and reverential and desecratory termination rituals (e.g. Pagliaro et al. 2003) that extended to cannibalism and human sacrifice (Dening 1978; Filihia 1999; Kyle et al. 2009; Sissons 2011). In a recent paper, Bedford et al. (2020) examined missionary 'battles' over spiritual objects central to indigenous beliefs on Aneityum that had to be weakened to support conversion to Christianity, as was noted on Mangaia by the missionary John Williams (Moyle 1984:25):

A very large Portion of the Inhabitants remain heathen; but their Idols temples have all been destroyed together with the Idols, so that it is Probable the whole Population will soon become Christians.

In Australia, the destruction and exclusion of Indigenous food supplies after European settlement has long been considered a major cause of cultural destabilisation (e.g. Rowley 1970), and more broadly colonialism and capitalist enterprises can be categorised as 'war capitalism' (Morrison et al. 2019). Missionary activity also contributed to cultural alienation, seen in the recent burning of Aboriginal sacred objects in the Kimberley. The missionary involved was from Tonga (Parke 2019), where representations of the traditional gods were hanged by the neck and displayed to Christian congregations in the nineteenth century (Neich 2007).

There are also behaviours and actions that are now classed-when viewed through the lens of contemporary standards - as 'violence', as with 'environmental violence' to describe the unsustainable use of fauna, flora and land in the past (Salcedo 2015), or the unintentional, but certainly predictable, population 'violence' wrought by the introduction of deadly pathogens to the 'new' lands and people of Australia and the Pacific (Crosby 1986; Igler 2015). Definitions of conflict and warfare abound, with most authorities viewing the use of interpersonal violence as a tool to achieve change in the sociopolitical position of an individual or a group relative to others (Kissel and Kim 2018:Table 1). Ember and Ember (1992:248) define warfare as: 'socially organized armed combat between members of different territorial units', while for Webster (1998:313), warfare consists of planned confrontations between groups of people who conceive of themselves as members of separate communities (factions) who organise and sanction group violence that may result in deliberate killings. The latter description encompasses the many kinds of conflict (e.g. homicide, feud, raid, ambush, chance meeting, battle) that are documented within and between pre-industrial societies, states and empires.

It is clear that conflict in the past has always had many dimensions and not all are currently amenable to investigation. As is common in archaeology, we are missing material evidence for an unknowable fraction of past human behaviour, and in seeking to understand conflict through limited data and a necessary level of subjective interpretation we run the risk of either pacifying the past or giving violence a societal prominence it never had. With these cautions in mind, we begin by outlining the early chronological evidence or 'residues' of past conflict in the Australia and Pacific region before identifying three areas where archaeological investigations might contribute to a deeper and nuanced historical understanding of aggression and conflict. These 
are: (1) The cause of conflict, particularly the role of resource shortfalls; (2) A frequent association between culture contact and violence; and (3) Why archaeological (and historic) evidence for conflict frequently patterns as punctuated events.

As archaeologists we are mostly concerned with the deep past through to the beginnings of the twentieth century, and with conflict affecting indigenous peoples, a perspective that omits many of the significant sites and experiences of the world wars. World War II, in particular, stands out in the Australia and Pacific, not just due to the scale of the conflict and its victims (Price and Knecht 2012), but also in its transformation of the region's economies and cultures, their increasing global integration and the growing postwar movement towards independence that was often accompanied by protest and resistance (Campbell 2009; Chappell 1993). Incorporating the material evidence and cultural experiences from relatively recent global events such as World War II (Ouzman et al. this volume; Price and Knecht 2012) and local conflicts (Kwai 2017) into our island and continental records of conflict is a challenge for researchers seeking to bridge an artificial and unnecessary division between conflict research of the past and the present.

The chapters in this volume explore only some of the issues raised above, as the geographic range and time depth of the Australia and Pacific region necessarily results in gaps in coverage, notably in areas of Melanesia and Micronesia, where a number of researchers were unable to complete papers due to the social and economic impacts from COVID-19. It was also apparent when contacting potential contributors that the archaeological study of violence in Australia is seen as highly sensitive, in part because the results may be misunderstood or misrepresented in contemporary debates.

\section{Residues of early conflict}

\section{Australia and Island Melanesia}

In land area, the Australia and Pacific region is dominated by the Australian continent, which is characterised by significant environmental and climatic variation and has been inhabited by Aboriginal populations for c. 65000 years (Clarkson et al. 2017; Williams et al. 2013). The oldest indications of past violence are depictions of 'warriors' in the Dynamic Figure rock art of Arnhem Land (Taçon and Chippindale 1994) that likely date to the late Pleistocene (Jones et al. 2017:86). Taçon and Chippindale (1994) have suggested that some Dynamic Figure designs depict one-onone skirmishes between combatants armed with boomerangs and barbed composite spears. Later art in 'simple figure' and 'energetic' styles may show organised battles between large numbers of combatants using weapons such as clubs, spear-throwers, hafted stone axes and barbed, pronged and stone-tipped spears. Unambiguous evidence for violence includes stone spear barbs (backed microliths) found in the remains of Narrabeen Man, dated to c. 3600 years ago (Fullagar et al. 2009; McDonald et al. 2007), and cut-marked bone from the more recent individual known as 'Kaakutja' (Westaway et al. 2016, see also Webb 1991 and Knuckey 1992). Consistent patterns of osteological trauma in Aboriginal remains suggest some level of violence and warfare among groups in the Murray Valley region over the past 7000 years (Brown 1989:176; Pardoe 2014).

Proximity to Australia, particularly during times of lower sea level during glacial expansion and periods of global cooling (Yokoyama et al. 2018), facilitated the spread of early modern humans through the merged Australia-New Guinea landmass (Sahul) and nearby archipelagos of western Melanesia at least 40 000-50 000 years ago (Summerhayes et al. 2010). The likelihood of some Pleistocene voyaging along the east Asian coast through to Melanesia is suggested by cultural deposits on Okinawa dated to c. 35000 years ago (Fujita et al. 2016), and Pleistocene-age sites on Manus Island and Buka suggesting that early humans could also have spread a further 
$1000 \mathrm{~km}$ into Oceania by island-hopping through the main Solomon Islands (Frederickson et al. 1993; Lilley 2010). Relatively little is known about early Melanesian populations in terms of their social organisation and propensity for conflict, despite the emergence of Neolithic settlements and interaction networks in island and mainland Papua New Guinea some 5000 years ago (Shaw et al. 2020; Torrence et al. 2013), a lifeway associated elsewhere with significant inter-group aggression (e.g. Bocquentin and Bar-Yosef 2004; Fibiger et al. 2013; Meyer et al. 2015).

\section{Lapita expansion and colonisation of West Micronesia}

The remote islands of Oceania, defined as those east of Makira (San Cristobal) in the Solomons, were settled much later than Australia-New Guinea, with dispersal from 3150 to 2850 years ago as indicated from ceramic-bearing sites of the Lapita culture that are found from southern New Guinea eastward to Tonga and Samoa. The c. $4500 \mathrm{~km}$ span of Lapita sites in the western Pacific over 200-300 years is consistent with the deployment of a new maritime technology (Anderson 2000). The introduction of better sailing vessels and enhanced nautical wayfinding in insular Asia is also implied by long-distance passages to western Micronesia (Palau, possibly Yap, and the Mariana Islands) at a similar time to the Lapita dispersal (Clark 2005; Petchey et al. 2018), which probably originated in east Indonesia or from migrant groups on the north coast of $\mathrm{New}$ Guinea (Montenegro et al. 2016; Winter et al. 2012).

Recent aDNA and obsidian sourcing results show that Lapita people had an ultimate origin in island Asia (Skoglund et al. 2016), and that after Lapita dispersal there were early and later secondary migrations of people from New Guinea-island Melanesia that resulted in population mixing between Lapita-derived populations and west Oceanic migrants (Hudjashov et al. 2018). Genetic analysis (mtDNA) of contemporary Chamorro people of the Marianas (Vilar et al. 2012) points to a founding population of island Asian derivation, with a second migration from the same region c. $1000 \mathrm{CE}$ that brought new cultural traits, including latte architecture, rice cultivation and mortuary practice.

Whether the migrations that came after Lapita settlement and human arrival in western Micronesia were accompanied by conflict is unknown, but the question is worth considering as inter-group violence frequently attends or is intensified by culture contact, both indigenous and from the expansion of Western societies (e.g. Bamforth 1994; Blick 1988; Hutchinson 1996; Knauft 1990). The sparse evidence for early conflict in Oceania consists of shell and basalt sling stones from a Lapita site in the Reef-Santa Cruz islands (Green 1979:39, but see Kirch and Green 2001:190). These distinctive double-pointed ovoid projectiles, mainly made in shell and stone, were designed to inflict serious damage to the body of an opponent, but have not been securely identified in the Lapita assemblages of Fiji, Tonga and Samoa, nor in early contexts in New Caledonia and the Mariana Islands, where they are predominantly associated with late prehistoric deposits (Sand 2001:81; York and York 2014). In these areas, unmodified and rounded sling stones may have been used (as in Fiji, Cook Islands and Marquesas, see Suggs 1961:27); in some places these were used to hunt birds, fish and other animals, while pointed sling stones are particularly associated with human inter-group conflict in many parts of the Pacific. It is unclear whether shaped sling stones in Reef-Santa Cruz Lapita sites indicate conflict during Lapita colonisation; if so, they would be the oldest surviving weapons present in Oceania. Shaped stones used in conflict and thrown by hand rather than from a sling are recorded from Niue Island (Isaac and Isaac 2011), Rapa Nui/Easter Island (Métraux 1940:165) and Tanna in Vanuatu, where cylindrical kawas stones were hand-thrown in inter-group conflicts (Turner 1861:81-82). 
In West Micronesia, the oldest Pre-Latte burials (3200-1000 years ago) in the Marianas are associated with a few sling stones dating to c. $500 \mathrm{BCE}$ or later, with the number increasing in latte burials made after 1000 CE (Walth 2016). York and York (2014:23) report the unpublished archaeological discovery on Guam of a human skull with a bipointed sling stone embedded in it. However, trauma in the skeletal remains of 370 individuals excavated from Pre-Latte (42 per cent) and Latte (57 per cent) contexts at the Naton Beach site on Guam did not suggest warfare in pre-contact populations, although the presence of more young males than females could reflect male hazards such as warfare (Walth 2016:16).

The earliest secure evidence for inter-group aggression in the Pacific Islands are earthworks with defensive traits made in Palau at c. 2500-1100 years ago (Liston this volume; Liston and Miko 2011:19; Liston and Tuggle 2006) and modified human bone consistent with cannibalism in Fiji before 1000 CE, and possibly as early as 500-100 BCE (Best 1984:562, DeGusta 1999; Pietrusewsky et al. 2007; Worthy and Clark 2009:244). Human remains at the Teouma Lapita site in Vanuatu (900 BCE) and the Talasiu burial ground (700 BCE) in Tonga bear small amounts of bone damage and modification that might result from interpersonal violence, but some of this damage likely derives from the complicated mortuary practices and bone manipulation techniques used by early colonising groups (e.g. Valentin et al. 2020).

Reconstructed terms in Proto-Polynesian (PPN; Kirch and Green 2001) for 'war' (PPN *tau), weapon (PPN *masafu) and fortified/enclosed settlement $\left(\mathrm{PPN}{ }^{*} k o l o\right)$ indicate the existence of organised conflict in Fiji-Western Polynesia sometime after 500 BCE. Caves and natural topographic 'defences' were used in the Sigatoka Valley of Fiji 2000 years ago (Field 2004), but distinguishing the archaeological evidence for raiding, refuge and conflict in unmodified sites such as ridges and caves (e.g. Carson 2017; Kyle et al. 2009) is problematic in the absence of weapons and built defences (see also Kolb and Dixon 2002:518-519). In New Caledonia, there are substantial forts in the Loyalty Islands, including the impressive Hnakudotit structure on Maré, with stone walls c. $10-12 \mathrm{~m}$ thick and up to $180 \mathrm{~m}$ in length that may date to c. $200 \mathrm{CE}$, from radiocarbon ages on marine shell found in the wall fill (Sand 1996; Sand pers. comm. 22 September 2020), but additional dating is required to confirm the structure's early age. Hnakudotit is only $500 \mathrm{~m}$ from another large fort called Waninetit (Dubois 1970), suggesting fort placement was to control a roadway or to protect clan boundaries. It is only within the past 1000 years that fortifications appear to have been regularly constructed in Fiji and adjacent island groups such as Tonga, Samoa, Futuna and 'Uvea (Burrows 1936; Clark et al. 2017; Sand 1993, 2008).

Injuries consistent with interpersonal violence and warfare have been identified in human remains, predominantly those of males, dating to the second millennium CE in Papua New Guinea (Nebira) and the Polynesian outlier of Taumako in the Solomon Islands (Scott and Buckley 2010). Piercing wounds from bone-tipped projectiles were present in the Taumako burial group (Buckley 2000), while blunt force cranial trauma was found in both Taumako and Nebira, but was particularly high among Nebira males (38.5 per cent), consistent with intergroup conflict and warfare (Scott and Buckley 2010). In Tonga, high rates of fractured radii in the people interred in the 'Atele burial mounds point to ritualised violence, possibly from combat sports such as boxing, club fights and controlled displays of public violence known to have been held at chiefly and community gatherings (Scott and Buckley 2014). The funeral ceremonies of Tongan high chiefs involved combat sports as well as public displays of self-harm that could involve the mourner cutting, burning, clubbing, spearing or stabbing themselves to demonstrate grief and affection for the deceased, and amputation of finger joints to influence the gods was common (Clark and Langley 2020; Martin 1991; Statham 2013). Interestingly, Pardoe (2014:127) notes self-harm in the funerary behaviour of Aboriginal groups on the Central 
Murray and Darling Rivers. Elite sacrifice is suggested from human remains interred at the burial site of the paramount chief Roy Mata in Vanuatu (c. 1600 CE), whose regime traditionally involved political reorganisation and warfare (Luders 2001).

In 'Uvea in West Polynesia, the remains of more than 150 people were buried together at the Petania burial mound around a beach rock burial vault, which is a mortuary structure used in Tonga for the interment of elites (Clark 2016; Sand and Valentin 1991). Oral traditions suggest the individuals belonged to a Tongan colony who were massacred, with the number of dead representing around 5 per cent of 'Uvea's pre-European population. However, Sand et al. (2006) note there was little evidence for violent death at the Petania site, although the presence of poorly healed forearm fractures among 'Uvean males was probably the result of aggressive behaviour. The massacre of Tongan colonists and fighters is widespread in traditional history from many parts of the Pacific, including Vanuatu, Fiji, Anuta, Futuna, 'Uvea, Samoa and Niue (e.g. Burrows 1936:126, 1937:29; Churchill 1911:46; Feinberg 1998; Loeb 1926; Smith 1903:11).

\section{East Polynesia}

Colonisation of East Polynesia 1000-700 years ago, most likely from 'homeland' West Polynesia, involved long-distance voyaging and some level of limited post-colonisation contact among widely dispersed island groups. This is shown by the distribution of Samoan stone adzes over $5000 \mathrm{~km}$ from Pohnpei to the Cook Islands (Clark et al. 2014; Weisler et al. 2016) and the settlement of more than 20 Polynesian outlier communities in Melanesia and Micronesia (Kirch 1984). Traditional history is unambiguous in describing the existence of warfare in many parts of Polynesia (Hommon 2013; Tau and Anderson 2008), which could be accompanied in places by the remains of specialised built sites such as linear defences, observation posts, palisaded compounds, war temples and large community fortifications made in earth, stone and wood (Best 1993; Irwin 1985; Kolb and Dixon 2002). Just as in Melanesia and Micronesia, defensive structures made of earth and stone were not universal among Polynesian societies (Green 1967, see below). Fortifications capable of community protection are most abundant in Aotearoa/New Zealand (Anderson this volume), reasonably frequent in Rapa Iti (Kennett and McClure 2012) and the Marquesas (Molle and Marolleau this volume), but rare or absent almost everywhere else. The islands/groups where fortifications are reasonably common share complicated topographies where the natural defensive properties of the land can be enhanced by group investment in construction (Field 2004). Islands or archipelagos consisting of atolls with a small land area and flat topography, such as the Tuamotus and Northern Cooks, do not have numerous built fortifications, yet neither do many rugged volcanic islands in Polynesia including most of Hawai $i$, Southern Cooks, Society Islands, Australs (excluding Rapa Iti) and Mangareva-illustrating that a decision to make fortifications was not influenced solely by physical geography.

On Rapa Nui/Easter Island, warfare was once seen as a prime mover for social change and cultural disintegration as a result of significant inter-group conflict, reported in oral traditions and seen in some archaeological data. This view has been questioned largely in response to Diamond's (2005) well-known view that a human-induced environmental catastrophe on Rapa Nui led to societal collapse. Injuries to human remains, mata'a obsidian flakes suggested to have been hafted to projectile and thrusting weapons, and cave refuges are no longer seen to offer support for the existence of endemic warfare and social breakdown (Stevenson and Williams 2018). There are only a few potentially defensive sites on Rapa Nui (Green 1967; Martinsson-Wallin this volume) and a recent paper by DiNapoli et al. (2019) suggests that:

Several emerging and independent lines of evidence show that there is little empirical support for violent warfare, including little evidence for the production of lethal weapons, limited instances of lethal skeletal trauma, and a lack of fortifications. 
While the archaeological data does not support large-scale warfare on Rapa Nui, as in most of Australia and the Pacific, there is good evidence for significant inter-group conflict probably involving raiding and aggression between prehistoric communities (Martinsson-Wallin this volume). The largest and most contentious defensive site on Rapa Nui is the 'Poike Ditch', which spans the eastern part of the island. In local oral traditions the area was a battle and massacre location associated with two groups known as the Hanau e'epe and Hanau momoko. The northsouth ditch consists of a series of linear ditch segments nearly $2 \mathrm{~km}$ in total length (Reanier and Ryan 2003). Investigations by Smith (1990) suggest the ditch was a natural geological fault where the fill had been dug out and deposited on the upslope side in a number of mounds or as a rampart. The site was originally interpreted as a fortification due to oral traditions of intergroup conflict (Routledge 1919:280-282), but researchers now suggest the feature could have been used for horticulture or was a cooking place for workers at the nearby Rano Raraku statue quarry. In a recent scholarly review of Rapa Nui warfare and conflict, DiNapoli et al. (2020) note that the Poike Ditch is of geological origin, but make no mention of the fact that sediment from the natural depression was excavated and placed in a mound/rampart on the upslope side of the ditch. The ditch was dug out to at least $2 \mathrm{~m}$ depth and is possibly over $3 \mathrm{~m}$ in depth, implying an upslope mound/rampart 2-3 m in height prior to erosion and ditch infilling (see Smith 1990:33). The earthwork at Poike, based on Smith's (1990) cross-section, therefore created a vertical obstacle 4-6 $\mathrm{m}$ in height with a gradient of $0.25-0.35$ that could have slowed attackers.

While the Poike feature may have been used for agriculture, water control or cooking, it is highly suggestive of a defensive earthwork, consisting of sections separated by gates/entrances that utilised the natural ditch to physically define and limit access to the eastern part of the island. New excavations and study of this enigmatic site are needed to resolve its age and function, along with other possible defensive sites (see Martinsson-Wallin this volume).

An extensive study of Rapa Nui human remains (minimum number of individuals, MNI = 469) mostly dating to $1647 \mathrm{CE}$ or later did not find evidence to support organised lethal warfare, yet found a high rate of male cranial vault fractures (30.4 per cent) especially among young adult males ( 37.7 per cent), likely caused by thrown stones and in some cases from clubs (paoa). Lithic fragments, probably of obsidian, were found in two crania, suggesting that mata'a were employed as weapons (Owsley et al. 2016:236, Figure 13.10). Geiseler (in Ayres 1995:72) noted that even in the late nineteenth century, after substantial population decline, obsidian mata'a points were hafted to spears and caused wounds that were hard to heal, while Flas (2015) suggests that mata'a were hafted as spears only after substantial post-contact population collapse. However, Johann Forster (1982:470) in 1774 CE recorded that: 'The Natives have a kind of Spear consisting of a Stick, to which a black sharp Flint is fixed, which they constantly wrap', suggesting that mata' $a$ were hafted multipurpose tools that could be used as weapons.

Clearly, violence was not unknown to Rapa Nui (Bahn 2015), but whether these skeletal injuries resulted from post-contact intensification in violence (see below) or from traditional forms of Rapa Nui combat between individuals and groups (raiding, feuding, ambushes, ritual combat) needs further study. According to the careful ethnographer Métraux (1940:74):

References to intertribal wars are frequent in Easter Island folklore. They reflect real conflicts between tribes (mata) whose quarrels and feuds ended only after the advent of the missionaries. 


\section{Resource shortfalls, warfare and exceptionalism}

Many archaeological studies posit resource shortages as a reason for conflict and warfare in the past, as outlined by the philosopher Thomas Hobbes (1588-1679 CE). Such conflicts have been termed 'wars of necessity':

The most frequent cause why men want to hurt each other arises when many want the same thing at the same time, without being able to enjoy it in common or to divide it. The consequence is that it must go to the stronger. But who is the stronger? Fighting must decide. (in Thivet 2008:707)

Spectacular evidence for early violence among hunter-gather groups is dated to c. 10000 years ago at the Nataruk site in Kenya: the site includes 12 individuals found over $260 \mathrm{~m}$ of palaeoshoreline, 10 of whom had likely experienced violent injury, including blunt force trauma to the head and injuries from lithic bladelets and microliths, which were found embedded in bone or found within skeletons. The Nataruk remains have been interpreted as a 'massacre' from a raid for 'resources' such as territory and stored food, and for women; the injuries seen to testify to a 'standard' antagonistic inter-group response (Mirazón Lahr et al. 2016). In the development of complex societies, the link between resource restrictions and conflict was highlighted in Carneiro's $(1970,1988)$ elegant model of circumscription theory. Competition for limited agricultural land and population growth in the model were the catalysts for inter-group wars that led to the formation of centralised political systems (chiefdoms) run by the victors. Over time, both the size of the political units and the geographic scale they controlled increased, eventually leading to the formation of early/archaic states.

Archaeological explanations of conflict from resource shortfalls/unpredictability are complicated because ideally, we would like to know which basic/essential resources were diminished, and by what amount, and we would like to be able to identify the cause(s) of resource declines. Population growth/pressure (see Shankman 1991) and climate events acting together or independently are commonly invoked mechanisms that can cause shortfalls. Numerous studies suggest that societies throughout the world experienced significant subsistence declines (Zhang et al. 2007, but see Oka et al. 2017), especially from drought, and increased conflict was the result (e.g. Buckley et al. 2010; Haug et al. 2003; Huang and Su 2009; Kaniewski et al. 2013), although the hypothesis is not without criticism (e.g. Caldararo 2015; Dittmar et al. 2019:75). The role of population pressure/density on land as a direct cause of conflict has also been queried in several archaeological and cross-cultural studies (Groube 1970:162; Keeley 1996:118-121; Nolan 2003:28; Robarchek and Robarchek 1992).

A simple feedback system in which climate-driven changes to subsistence lead to societal 'collapse' has been suggested for north-west Australia from 3200-1300 years ago (McGowan et al. 2012), and has been proposed across the Pacific when cooling associated with the 'Little Ice Age' led to a drop in sea level. Nunn (2007a, 2007b) has argued that between the Medieval Warm Period and the Little Ice Age there was a century or two of rapid cooling in the Pacific, termed the 'AD 1300 event'. This marked a rapid transition from a warmer to a cooler, stormier period, when sea levels dropped $60-80 \mathrm{~cm}$ from cyclical variation in solar irradiance. The combination of rapid sea level fall and increased storminess is argued to have caused a dramatic reduction of up to 80 per cent in available food resources (Nunn 2003:224, 2007c:121). This disturbance to the resource base resulted in increased competition and conflict across the Pacific, represented in some areas by the construction of fortifications and in others by a shift from open settlement locations to occupation of naturally defensible areas. Other signs of aggression were a rise in violent social practices such as cannibalism and headhunting (Nunn 2007a, 2007b). 
In Australia, ethnographic sources examined by Allen (2014:106) indicate that basic resources were highly defended and entire groups were sometimes eliminated in conflicts over them, with the caveat that sacred places (frequently waterholes) were often the 'resource' involved. The indivisible nature of many cultural and subsistence resources suggests that explanations of conflict that highlight access to basic resources may be too narrow. In Central Australia, Kimber (1990:163) notes that conflicts were probably more frequent in well-watered areas where population density was highest and during journeys that crossed clan boundaries to procure red ochre and the pituri stimulant. Other ethnographies, such as the accounts of William Buckley (Morgan 1980), mention that many conflicts were over women, in addition to those involved in long-distance expeditions to obtain stone axes, and payback for death attributed to 'magic'. The latter is not mentioned by Allen (2014) as a reason for inter-group violence yet the application of 'magic' could involve revenge killings, surprise raids and the deaths of men, women and children (Curr 1883:311-320). The main point is that resource shortages are seldom mentioned as a reason for Aboriginal conflict by ethnographic observers and in some cases inter-group aggression took place when food sources 'seemed inexhaustible' (Morgan 1980).

Similarly, among Pacific societies the ethnographic motivations for conflict and warfare only rarely mention basic resources, particularly land, among a range of reasons (Anderson this volume; Younger 2008, 2009). For the Maori, cultivable land, fishing grounds and eel weirs were causes of friction, but so too were murder, magic, infringement of tapu (traditional prohibitions) and slights to an individual/group (Ballara 1976). Land is a basic resource necessary for subsistence and group survival, but when developed through cultivation and land management practices such as arboriculture and intensified dryland and irrigated agricultural systems, the land and the people who work it are frequently viewed as a political resource that is sought or destroyed to strengthen the position of leaders, communities and states relative to others (see Earle 1997; Parry 1981). For many groups and societies, control and/or management of 'basic resources' is not strictly about group survival and is often prompted by a desire to maintain and expand existing economic and social systems.

The traditional motivation for raids, headhunting and wars in the Marquesas was to obtain human sacrifices for local deities as well as reciprocal conflict to avenge those who had been sacrificed by rival groups (Dening 1978; Molle and Marolleau this volume). Insults to tribes and chiefs could also result in wars where individuals and groups could enhance their prestige. Wars appear only rarely to have led to control over land, with agreed battle sites located in upland valleys. Inter-group conflict might be stopped when a sacrifice was taken, plunder was obtained, the enemies' religious images were stolen or a truce was called to hold agricultural or funerary ceremonies (Handy 1923:123-141). Raiding and warfare in Palau (1000-1800 CE) was strongly linked to the political position of chiefs and villages, with headhunting raids used to obtain traditional money (udoud) used in chiefly politics. Pitched battles were undertaken to become the paramount village in a district, to acquire prestige items and valuables, and to create a tribute relationship with weaker settlements. Punitive wars were also made to stop lower ranked villages from challenging the district hierarchy (Liston and Tuggle 2006; Parmentier 1987).

Conflict to maintain, and if possible, extend influence through subjugation of tribute-paying villages is also reported from Fiji, with wars between rival chiefs challenging for political supremacy. Wars also occurred within chiefly families for leadership, and conflict could be precipitated by insults, portable valuables, the breaking of traditional laws and, as in the Marquesas, the common use of human sacrifices to appease war gods. As Wilkes observed during a visit to Fiji in $1840 \mathrm{CE}$ :

The wars of the Feejeeans [Fijians] usually arises from some accidental affront or misunderstanding, of which the most powerful party takes advantage to extend his dominions or extend his wealth. (Wilkes 1985:78) 
According to Clunie (2003:7), the most serious and destructive conflicts in Fiji were between tribal confederations headed by paramount chiefs who were personal enemies, which could result in sacking and the depopulation of large tracts of land and entire islands. Traditional history in Tonga, where a centralised polity developed (1200-1800 CE), is unequivocal in linking warfare with political upheaval, particularly attempts at regime change when members of the paramount Tu'i Tonga line were assassinated c. 1450-1500 CE (Clark 2016; Parton et al. this volume). A similar situation is noted for late pre-contact Hawai $i$, where warfare was common after the death of a king when the heir was challenged by collateral kinsmen (Kirch 2010:71). Insults and disputes over high titles, especially following the assassination of a paramount chief, are recorded as the main cause of war in Samoa (Krämer 1995:392).

The above examples suggest two serious limitations to the idea that 'resource shortfalls' were a primary driver of conflict and warfare in the past (see also Ember and Ember 1992; Younger 2008, 2014). First, archaeological explanations that link conflict/warfare with resource shortages frequently diverge from instances of inter-group aggression in emic accounts as well as explanations for aggression put forward by external observers. For instance, Dye (2014:64) has noted that in several Hawaiian traditions a consequence of severe drought and famine was a food-sharing ethic rather than social disruption and war. A review of pre-contact warfare in Melanesia identified conflict over land rights, women, and individual and group prestige that was necessary to assert identity. Not only was Melanesian warfare largely characterised by an 'absence of territorial ambition', conflict also appeared to be driven by a desire for political stability and balance with reciprocity a fundamental aspect of inter-group violence in many societies (Younger 2014). In islands near Malekula in Vanuatu, wrote Layard (1942:588), wars were made almost entirely on questions involving the prestige of one group against another, in order to maintain the existing order of society by wreaking vengeance on any who seek to disturb it', with violence mainly over women, insults, trade and kinship relations, or resources such as pigs.

One reason for diverging views about the cause of conflict in archaeology, compared with other disciplines and sources, might be that the ecological and population circumstances leading to conflict are of such complexity and duration that they cannot be recognised by the participants/ observers themselves (Vayda 1970:570, 1976). Resource declines in the past might therefore be deduced from archaeological and environmental records. However, this seems unlikely given: (1) A general absence of high-precision environmental archives for many conflict locations; (2) An incomplete and often mute archaeological record regarding the motivation for conflict; and (3) An untested assumption that indigenous groups are unable to perceive the reason(s) why they engage in conflict.

The second limitation to the idea of resource scarcity as a driver of warfare is that a connection between conflict and resource scarcity is largely absent from records of societal aggression from classical antiquity through to the modern era. If writers of history concerned with large and small conflicts from Herodotus and Thucydides through to Clausewitz (1984) and Hintze (1975) fail to mention basic resources as a reason for inter-group aggression, then we might consider whether archaeology and some strands of evolutionary archaeology have adequately established a causal connection. Is the appeal to resource shortfalls to explain conflict in archaeology justified by our data? Are conflicts involving ancient communities, states and empires really so different from those of recent times? The historian of contemporary warfare Betz (2019:32) has observed that major NATO installations in Afghanistan were 'located about one day's march apart, essentially where Alexander the Great placed variants of them 2,500 years before'. He might have added that conflict in this region, then as now, was not over the acquisition of basic resources (see Arrian and de Sélincourt 1976). Appeals to 'historical uniqueness' (Weiner 1971:666) and 'chronocentrism' (Fowles 1974) need to be scrutinised carefully, both when archaeological reasons for conflict in the past diverge from the causes of conflict and warfare outlined in detailed historical accounts 
spanning thousands of years and when they are not strongly supported by analyses of recent conflict. Wimmer and Min (2006:894) caution against explanations of warfare based on modern 'unprecedented' circumstances, which 'represents yet another example of the widespread tendency among social scientists to perceive their own times as unique and exceptionally dynamic'.

A final point about resource shortages as an explicator of aggression in the archaeological record is the question of event order. Declining food yields/basic resources are often seen as the prime mover for societal disruption that leads directly and quickly to systemic intergroup conflict (e.g. Nunn 2003, 2007a, 2007b). Historical observations, however, suggest that in several instances the impacts of famine and resource shortfalls were created or made significantly worse by conflict and warfare (see also Zhang et al. 2007). During the late eighteenth and nineteenth centuries in Tonga, political upheaval and assassination led to polity fragmentation and civil war c. 1792-1852 CE. During this lengthy interval it was observed that famines and subsistence shortfalls were a direct and predictable outcome of conflict (see also Layard 1942:599):

they usually made war by attacking the taro and yam-grounds; these they plunder and destroy, which ultimately produces a famine, not only to their enemies but to themselves. (Wilkes 1985:28)

In modern times some of the worst famines and declines in food production, such as those that affected Syria, Sudan, Somalia, Ethiopia and Cambodia, have been caused or intensified by prolonged wars and repressive or poor governance (e.g. Clarke 2000). The relationship between resources and conflict is complicated, as in Syria where drought caused the relocation of around 250000 farmers to urban areas, which directly contributed to the outbreak of serious and ongoing civil war. Even in this instance, political instability, mismanagement and drastic water reductions caused by river damming contributed to the severity of drought, forced migration and conflict (Al-Muqdadi 2019). In short, conflict to secure basic resources is often used to explain violence in the archaeological record whether there is sufficient evidence for it or not (see Dittmar et al. 2019:75). An outcome of this is that we know little about why some societies appear to deal with significant climate and drought events while others experience warfare, fragmentation and collapse.

\section{Culture contact and conflict}

If initial meetings are a guide to future relations, then European arrival in much of Australia and the Pacific was highly discouraging, with many encounters characterised by violence and death. One of the earliest but least known events occurred during the first European crossing of the Pacific Ocean by a small fleet under Ferdinand Magellan, which reached Guam in $1521 \mathrm{CE}$ after a voyage of more than three months. After the local Chamorro people had taken items from the ships, they took the skiff from Magellan's flagship, whereupon the captain became 'very irritated' and took ashore an armed party of 40 men that burned 40-50 houses and killed seven or eight people. The account of Antonio Pigafetta (Pigafetta and Robinson 1906:92) records that before the punitive party left the ship, the killing of Chamorro people was anticipated: 'some of our sick men begged us that if we killed men or women, we should bring their entrails so that the sick men would be cured immediately'. The crew were suffering from severe scurvy and while there is no evidence that the dead were mutilated it is perhaps unlikely that such an atrocity would be recorded in an account meant for an elite and Catholic readership in Europe. Nonetheless, in an inversion of popular expectations, first contact in the Pacific almost certainly involved a plan by Europeans to cannibalise slain Pacific Islanders. 
Other expeditions and brutalities followed. Soon after Mendaña's arrival in the Marquesas (1595 CE), the bodies of three murdered Marquesan men were displayed on shore to demonstrate the effectiveness of Spanish weapons and 200 Marquesan people were estimated to have been killed in under three weeks (Markham 2016:24, 26). On Santo in Vanuatu, first contact by Quirós (1606 CE) involved a plan to teach indigenous people Spanish and to catch some natives so as to establish peace and friendship'. Inevitably, this approach failed to foster cordial relations and soon after the Spanish landed, a local man was killed and his beheaded body hung in a tree, presumably as a warning not to attack the new arrivals, which predictably resulted in escalating cross-cultural violence (Markham 2016:242).

Serious conflict was not universal during the phase of European exploration from the sixteenth to the late eighteenth century, but was more common than not. To cite two instances that occurred long before James Cook's well-known voyages to the Southern Hemisphere (1768-1779 CE), Janzoon's 1606 CE voyage in the Duyfken to northern Australia and New Guinea involved resistance by the Wik-Mungkan people and killings on both sides (Mutch 1942; Sutton 2008), while in southern New Guinea also in $1606 \mathrm{CE}$, food, converts and 'plunder' were taken from Mailu Island after major fighting and storming of the local fort, where, Prado relates: 'I was sorry to see so many dead children' (Stevens and Barwick 2010:153).

Early contact was accompanied by violence in other Pacific Islands, including Chuuk (1565 CE), Tonga (1616 CE), New Zealand (1642 CE), Society Islands (1767 CE), Rapa Nui (1722 CE), Hawai' $i$ (1778-1779 CE) and Samoa (1787 CE). It is necessary to understand a strong association between violence and conflict during early contact and subsequent colonial activity in Australia and the Pacific, as archaeological studies can add nuance and new interpretations to historical records, and cross-cultural conflict may be important aspect of inter-group contact in the past.

There are at least two modes of conflict in early contact records. The first has been characterised as a result of the shock of the new, and the idea that when 'different worlds collide', violence is a likely outcome. Reasons for friction include the European need to reprovision after long ocean passages, views of indigenous people as 'savages' (noble or ignoble), difficulty in communicating and understanding social norms, and local demand for exotic materials. Other aspects were also important as both pre-Enlightenment and Enlightenment voyages were crewed almost entirely by males, many of whom had military or naval backgrounds and who were trained in the use of weapons. The small size of crews relative to island populations and their extreme isolation from aid meant that violence was often used as a form of boundary maintenance.

The fact that visiting ships were armed and usually crewed entirely by males equipped with weapons suggests that Europeans were seen as potential raiders or aggressors because many indigenous societies associated the arrival of armed all-male groups with raiding and inter-group conflict (Clark 2017). Such a perception would have been reinforced by the performance of military drills and the demonstration of weapons that, while designed to avert conflict, may have had the opposite effect, in addition to behaviours and ceremonies that were viewed as assertions of sovereignty. This was the case after Spanish arrival at Big Bay on Santo in Vanuatu (Markham 2016:243) and at Tahiti, where a well-armed shore party from the Dolphin took formal possession of the archipelago by erecting a naval pennant on a pole (Robertson 1973). It can also be seen in Aboriginal (Gweagal) resistance to Cook's landing at Botany Bay, summarised in his observation that 'all they seem'd to want was for us to be gone' (Cook in Beaglehole 1968:306), and in Vanuatu where Cook pondered how exploration might be viewed by the 'discovered': 
its impossible for them to know our real design, we enter their Ports without their daring to make opposition, we attempt to land in a peaceable manner, if this succeeds its well, if not we land nevertheless and maintain the footing we thus got by the Superiority of our fire arms, in what other light can they than at first look upon us but as invaders of their Country. (Cook in Beaglehole 1969:493)

Early contacts that involved conflict should, in many instances, be viewed as an entirely predictable response to territorial intrusion (e.g. Dillon 1829:145) rather than mutual 'misunderstanding' from the collision of different cultures.

The second and more complicated dimension of conflict during the subsequent phase of colonial emplacement and expansion has been well canvassed (e.g. Morrison et al. 2019) and we confine ourselves to comments about changes to 'traditional' conflict and warfare, especially the issue of whether indigenous violence intensified in the colonial era. Conflicts within and between indigenous groups are argued to have been relatively common in Australia and the Pacific, and there is a considerable literature, and debate, about the expression, frequency and scale of 'traditional' conflicts in post-contact settings. The severity of inter-group violence witnessed may be related to demand for new goods in post-contact tribal societies (Blick 1988). Guns, glass, metal and many other new items were rapidly incorporated into Aboriginal societies (Harrison 2002a, 2002b; May et al. 2017). The seemingly innocuous addition of new items of material culture was studied by Sharp (1952), who found that the introduction of steel axes to the Yir Yoront undermined gender, kinship and totemic relations and contributed to high levels of social and psychological stress, which was linked with the possibility of symbolic, if not actual, aggression.

Rates of lethal aggression among hunter-gathers outlined by Gat (2015) may therefore be influenced by social destabilisation due to contact and colonialism. Fry (2006), in contrast, has argued that within-group murder/feud was more common in Aboriginal societies, while intergroup conflict, raiding and warfare were rare. The topic of conflict is largely absent from recent scholarship (see Allen 2014) including Bruce Pascoe's (2014) influential Dark Emu, except in relation to European invasion and settlement. If agriculture and other resources underpinned Aboriginal sedentism and higher population densities, as Pascoe suggests, then these factors in particular areas might also have led to significant conflict and inter-group warfare. We currently lack robust data and archaeological frameworks to distinguish between the range of plausible alternatives due, in part, to the entirely appropriate cultural and political sensitivities concerning the study of Indigenous remains (see Pardoe this volume). Nonetheless, we think it probable that some ethnohistoric records of Aboriginal inter-group violence were influenced by social instability, shrinking territory and a colonial environment where institutional discrimination and marginalisation was accompanied by violence and massacre on the frontier.

Turning to the Pacific, an increase in internal conflict is seen in several island groups after European contact (DiNapoli et al. 2020; Martin 1990). Some of the significant contributors to violence include demographic decline and social upheaval from introduced diseases, the introduction of metal weapons (hand and projectile), and the erosion of political and religious belief systems as colonial and foreign influence grew. In Aotearoa/New Zealand, Anderson (this volume) found that warfare was intensified by differential access to European muskets and cannons (see Vayda 1970), as is also reported in Vanuatu (Layard 1942:602-603), Hawai'i (D’Arcy 2000), Tonga (Martin 1990) and Fiji (Clunie 2003), although the impact of new weapons was not universal even within an archipelago (Shineberg 1966).

Traditional conflict in many parts of Oceania was frequently reciprocal, with impasses common and shifts in power and territory difficult to maintain. The introduction of new weapons to a segment of the population could be a decisive element, as in Palau where the paramount 
chief of Koror (Ibedul) successfully defeated his enemies in four engagements with the help a shipwrecked English crew equipped with cutlasses, pistols and muskets and, at times, a swivel gun (Clark and de Biran 2010). In Tonga, a fort at Nukualofa that had resisted traditional warfare for 11 years was taken in $1806 \mathrm{CE}$ with the help of guns, cannons and crew forcibly taken from the Port au Prince (Martin 1991:82), and European mercenaries and their muskets in Fiji had a 'profound influence' on the rise of the Bau polity (Parry 1977:22). The demand for guns in Oceania was met by land, pigs, sandalwood and bêche-de-mer, and also women, creating new economic systems and port settlements that depended on foreign vessels (Quimby 2011).

Introduced diseases were disrupting populations in Australia and the Pacific at or soon after European contact (e.g. Crosby 1986; Richards 2004; Shell 1999). The first recorded epidemic in Tonga was in the 1790s (Martin 1991:66) after the arrival of missionaries who recorded that: 'Till the Europeans visited them, they had few disorders among them ... The case at present is wofully [sic] altered' (Wilson 1799:381). Traditional history in Fiji links two major pandemics with early contact by the Argo (1800 CE), which brought a wasting sickness (lila balavu), and the El Plumier (1802 CE), associated with dysentery (thokandra) (Im Thurn and Wharton 2010). The historical demographer McArthur (1967:96) suggested that epidemic transmission may have been slower in Tonga due to sporadic contact between islands, yet there were high rates of intraand inter-archipelago voyaging during the peak of the sandalwood trade in Fiji (1802-1812 CE), when European and American ships competed for the valuable timber. The point here is that Tongans had long travelled to Fiji to procure sandalwood and had European trade goods to exchange for Fijian products such as the large double canoes that not only increased chiefly trade but, like European vessels, were the means of spreading disease. This is shown by the arrival of an epidemic (ngangau) that killed many people in Tonga in $1811 \mathrm{CE}$ and which likely originated in the Fijian sandalwood trade and was brought to Tonga in two canoes procured in Fiji (Statham 2013:85-86).

New weapons, economies and diseases contributed to social instability, as did the arrival of foreign ideologies and belief systems that competed with, and undermined, traditional power structures (Dening 1978). This is exhibited in the Pacific by the number of monarchies, both nominal and substantive, that emerged in the contact era in Hawai $i$, Tonga, Fiji, Samoa, New Zealand and the Society Islands. These employed European weapons and influence to try and create new nation-states, including several that had imperial aspirations (Gunson 1969). The adoption of European political systems to exert control over an entire archipelago is noteworthy, as war group size and conflict causalities appear to scale with population size (Oka et al. 2017). In Fiji, the rise of the Bau chiefdom in the 1840s instituted conflicts with other polities that involved 'warfare on a scale and of a barbarity hitherto unknown' (Derrick 1974:75; also Sahlins 1991), while in Hawai i battles for regional consolidation by Kamehamea I involved conflict at 'unprecedented levels' (Kennedy and Brady 1997:651).

New trade and exchange networks brought diseases and were accompanied by social reordering due to the arrival of different forms of Christianity, most of which were highly critical of the indigenous gods and religious customs that were interwoven through traditional socio-economic structures. Chiefly power and authority in Oceania derived from practical and religious roles, particularly those that maintained the health and wellbeing of the people. Introduced epidemics eroded traditional leadership directly by killing leaders and indirectly by showing that when faced with serious diseases the gods, chiefs and traditional medicines were ineffectual or worse: in Polynesian societies it was common for disease and death to be viewed as divine punishment for religious transgression (Burrows 1937:92; Martin 1991:331). In contrast, Christian missionaries were offering a non-elite religion and showing its power through the efficacy of foreign medicines. The connection between exotic medical treatment and support for Christianity was apparent to at least some missionaries: 
its [medicine] skilful and successful application is one of the best means of gaining influence among the people and predisposing them to regard with favour his endeavours to direct their minds to the heavenly Physician. (Ellis 1844:159)

Thus, in parts of the Australia-Pacific region, indigenous conflicts appear to have occurred at either a higher frequency, a greater intensity or a larger scale after culture contact and colonialism, although we are yet to fully understand all of the factors and reasons involved in a rise in internal conflict. For example, traditional kinship and ranking systems may have had a significant role in promoting conflict when several individuals had a valid claim to leadership positions in sociopolitical systems that were weakened by colonialism. Societal decline accompanied by conflict was often a reason for extending European control, including through punitive expeditions, which eventually reduced violence from the imposition of colonial rule (Bedford this volume; Best 1993; Irwin et al. 2019).

The impact of colonialism in Oceania suggests that previous significant episodes of non-European culture contact-which may have included elements of colonialism, such as the arrival of migrant communities - could be represented in an archaeological record of heightened violence. There are many potential examples of indigenous 'colonial' conflict that would benefit from archaeological investigation. These include aggression between Polynesian migrants from Tikopia and the Melanesian inhabitants of Vanikoro (Stanbury and Green 2004:138); the use of force and coercion by the Saudelur dynasty on Pohnpei, which traditionally overcame local opposition and instituted centralised control from the monumental Nan Madol site (Hanlon 1988); the overthrow of Tongan rule in Samoa by the founders of the Mālietoa title (Gifford 1929:52); the role of warfare in the powerful Roy Mata chiefdom of Vanuatu, which recent aDNA results suggest was influenced by Polynesian migration (Lipson et al. 2020); and Macassan conflicts with North Australian Indigenous communities (Macnight 1972:288).

\section{Warfare and conflict as punctuated events}

Historians have long commented that many conflicts appear as episodic and punctuated events (e.g. regional conflicts, the life cycle of empires and world wars), particularly in complex societies where cycles of violence and warfare are viewed as intrinsic drivers of system change. The Chinese dynastic cycle and Ibn Khaldun's (1332-1406 CE) model of state development associate political and moral corruption with economic and leadership collapse. Strong political systems begin with experienced military-civil leaders who overthrow corrupt and/or disorganised regimes and govern fairly, allowing a cohesive society to emerge and prosper. Over time, corruption and poor management, especially from self-interested and hereditary elites, increasingly burden the productive populace, which weakens and fragments society. Conflict and warfare, whether internal, external or a combination of both, resets the unbalanced political system to begin the next cycle. In Turchin's (2006) war-peace-war cycle, highly unified groups form at metaethnic frontiers, which separate groups and peoples with very different belief systems from one another. Competition and warfare at ethnic frontiers foster high social cohesion (Ibn Khaldun's asabiya), which drives military success and imperiogenesis. Eventually the number, and demands, of elites grows too large, social cohesion is lost and internal war breaks out, causing the 'death' of expansive states and empires. Scheidel (2017) also identified a progression from secular 'integrative' societies marked by relative equality (high cohesion) to later states where there was drastic inequality. Severe inequality can only be reversed, in Scheidel's persuasive analysis, by extreme violence from one of four sources (catastrophic epidemic/pandemic, complete economic collapse, mass-mobilisation warfare, transformative revolutions). Historical studies support the idea that poor governance, growing inequality, the enrichment of elites and increasing inflation/ taxation precede conflict and collapse of complex societies primarily through destruction of the peasant-agrarian foundation (Tainter 2009:150-151; Yu-Ch'uan 1936). 


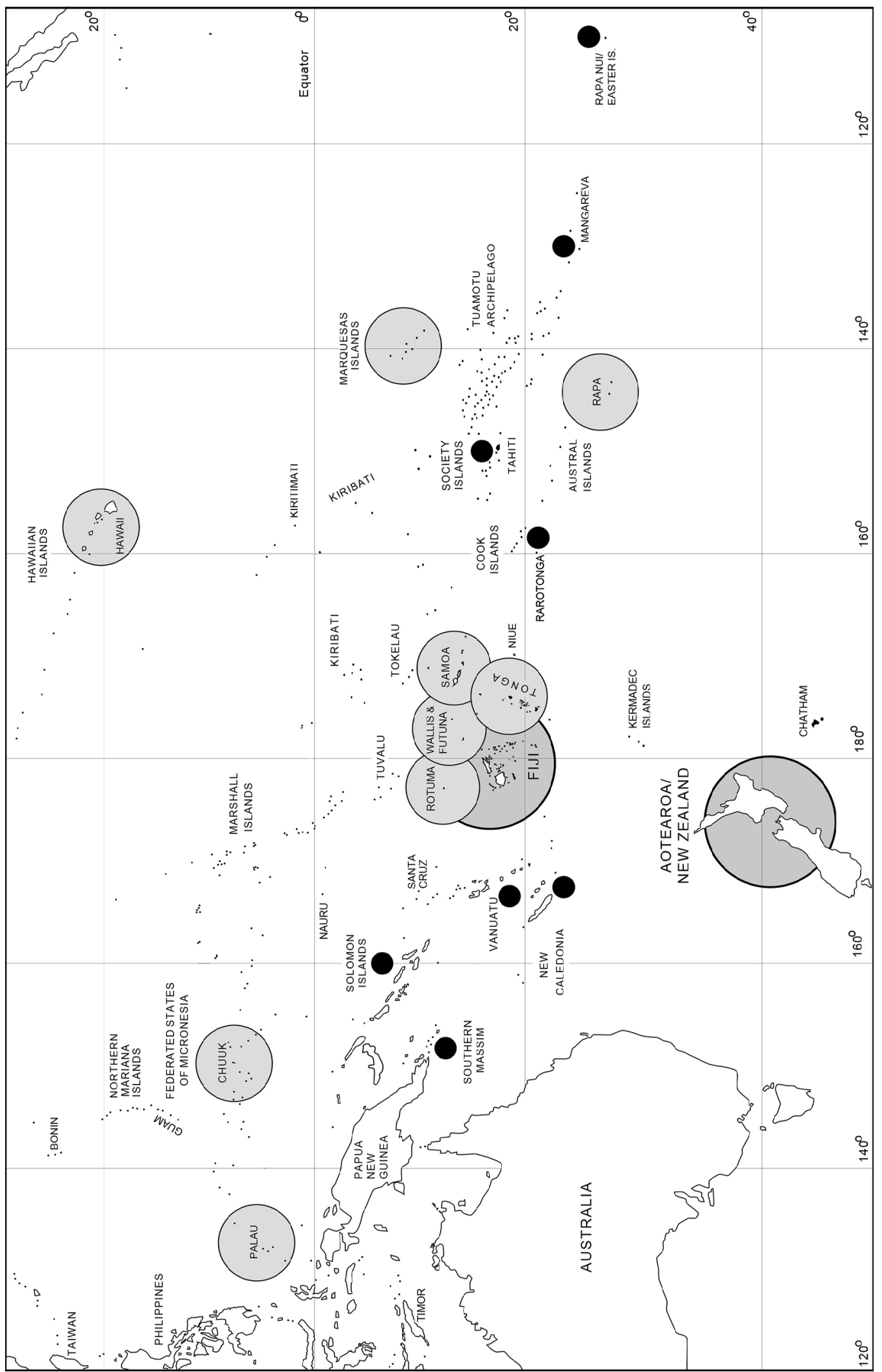

Figure 1.1. Relative abundance of fortified/defensive sites in the Pacific.

Based on Field and Lape (2010:Table 1) with additions as noted in the text (does not include west New Guinea forts mentioned by Wright et al. 2013). Note the presence of forts throughout Fiji-West Polynesia.

Source: Geoffrey Clark. 
In contrast, some archaeologists and historians associate peaks of inter-group conflict in the past with reduced agricultural productivity caused by climate forcing, particularly colder and drier periods (Zhang et al. 2007), such as in the Little Ice Age (LIA, c. 1450-1850 CE). It is difficult to examine whether conflict in Australia and the Pacific has peaks and troughs that correlate with climate events although the potential exists for detailed chronological analyses of violence in rock art images, human remains and weapons to compare with palaeoclimate records. Fortifications have been used to examine a connection between climate events and conflict in the Indo-Pacific, with important work by Field and Lape (2010:121) indicating that in the tropical Pacific 'fortification construction is linked to drought, or more specifically, to subsistence systems that are significantly impacted by drought'. Elsewhere, Di Cosmo et al. (2018) present evidence that a seven-decade-long drought did not cause the Uyghur empire to collapse, wage war or decompose into simpler sociopolitical units, while the role of drought in the demise of the Khmer empire is also questioned (Caldararo 2015).

The link between fortification building and the LIA was based on the age and location of 8761 fortifications in the Pacific Islands (Field and Lape 2010:Table 1, excluding forts in Okinawa, Indonesia and Timor). The majority of fortifications in the study were in Aotearoa/New Zealand (6796) and Fiji (1523), comprising 95 per cent of the total. Smaller but significant numbers of fortifications/defensive sites are found in Palau (Babeldoab 253), Samoa (46), Tonga (39), Rapa Iti (35), Chuuk (26), 'Uvea (22), Hawaiian Islands (16) and Rotuma (14). In other areas there were only a few fortifications (Maupiti 1, Rarotonga 1, Marquesas 4, Maré Island 1, New Georgia 1). Since the data was compiled, additional fortifications (Figure 1.1) have been identified in ethnohistorical records, and archaeological and remote sensing surveys (e.g. Wright et al. 2013) including in the southern Massim (Irwin et al. 2019), Solomon Islands (Codrington 1901:301; Sheppard et al. 2000), Vanuatu (Layard 1942:596), New Caledonia (Sand 1996; pers. comm.), Fiji (Burley et al. 2016), Tongatapu (Parton et al. 2018), Mangareva (Green 1967) and the Marquesas (Molle and Marolleau this volume).

Fortified sites generally contain defensive structures that impede or control movement, such as walls, ditches, banks, causeways and pits in sites that vary in scale from large hillfort-ridgeline complexes to linear fortifications, enclosure defences (enceinte), observation posts and refuges (e.g. defended caves, landscape high points). Ritual and/or high-status structures in defended areas can also be used for controlling movement with built architecture. Best (1993) and Keeley et al. (2007) discuss features of defensive constructions, particularly ditches made for agriculture, water management and transport. On Rotuma the 'fortifications' listed by Field and Lape (2010) were described by Ladefoged (1993:253) as 'possible' defensive lookouts located on hilltops, as the sites did not have typical earth or stone defensive constructions. It is probable that many archaeological settlements, and perhaps the hill sites on Rotuma, were once defended by wooden palisades that have perished (e.g. Suggs 1961:163). It is also useful to note that inter-group raiding and warfare in several island groups did not necessarily involve earth and stone defences, but relied instead on placing warriors/young men in strategic locations, as in Palau (Babeldoab) and Yap, where men's houses guarded road and wharf access to villages (Liston this volume, see Younger 2009). Similarly, in Guam in $1526 \mathrm{CE}$, where built defensive sites were rare/absent:

They make war among themselves. The weapons they have are slings, and fire-hardened sticks. They also place at the tip of some sticks the shinbones of men they have killed in battle, and which they also use to fight with. (Urdaneta in Lévesque 1992:465)

The location of sites on high points and in association with significant communication corridors (marine and terrestrial) is suggestive of strategic control and/or observation, whereas substantial fortifications indicate a community-scale military/defensive role (e.g. Clausewitz 1984; Parton et al. this volume; Reepmeyer et al. this volume). 
Some of the fortifications listed by Field and Lape (2010), such as the earthworks in Palau and stone forts in New Caledonia, clearly predate the LIA, while others were made in the eighteenthnineteenth centuries after European contact (see also western New Guinea forts in Wright et al. 2013). Detailed study of early fortifications would help to show whether climate events and potential resource shortfalls coincide with the development of elaborate defensive structures in New Caledonia and Palau prior to the LIA. Recent fortifications dating to the nineteenth century include the majority of Tongan earthwork fortifications built after the collapse of centralised rule, which caused a lengthy civil conflict among regional chiefs and their followers (Gifford 1929; Statham 2013; Parton et al. 2018), an unknown number of Fijian forts associated with significant conflict among nineteenth-century political confederacies (e.g. Burley et al. 2016), and forts used in post-contact warfare in Samoa (Davidson 1974:241; see also Best 1993). More than 500 fortifications were made during the New Zealand Wars (1843-1881 CE), with 322 made by Europeans and 183 by Maori (Prickett 2016). It is feasible therefore that a proportion of defensive sites listed by Field and Lape (2010) were constructed in response to social destabilisation following European contact rather than in reaction to LIA conditions. In addition to the structures already mentioned, post-contact fortifications were also probably made and used on Chuuk (Rainbird 1996:470), New Georgia (Sheppard et al. 2000:25-26), Marquesas (Suggs 1961:163), Hawai'i (Kennedy and Brady 1997), Society Islands (Green 1967:103-104), 'Uvea (Burrows 1937:83-84), Rotuma (Howard and Kjellgren 1994) and the northern Marianas (Burney 1813:308).

Nonetheless, many defensive sites and fortifications in Oceania were constructed during the LIA and warfare appears to have been endemic in several areas well before European contact (Knauft 1990). Fortifications in Oceania have a patchy distribution (Groube 1970:133) that is largely inconsistent with direct cultural transmission, with one important exception. For instance, the ridgeline forts of Rapa Iti do not occur on other Austral Islands, and in Palau early and late defences (e.g. those in the Rock Islands) are not found on Yap or the Marianas. There is no obvious source for the $p \bar{a}$ earthworks of New Zealand in Central Polynesia (Green 1967), and $p \bar{a}$ were not introduced to the Chatham Islands that were settled by Maori (Anderson this volume). An alternative to direct transmission is that the practice of surrounding settlements and compounds with wooden palisades/fences $\left(\mathrm{PPN}^{*}\right.$ kolo) was an early and widespread development. Palisades were eventually combined with ditch and bank earthworks, or the settlement boundary in rocky areas could be rendered in stone. Excavations in Fiji-West Polynesia show that earth and stone residential and burial structures date to at least 1000 CE (Best 1984; Field 2004; Frimigacci and Sand 2016). In Tonga, earth mounds were commonly formed by excavating a ditch around a residence, with the soil used to create a raised house foundation, suggesting that the architectural elements of palisade/ditch and bank fortifications were in place by the time East Polynesia was colonised (Wilmshurst et al. 2011), but were only brought together to make fortifications in some island groups.

The exception to the patchy distribution of forts noted above is a well-defined cluster in the FijiWest Polynesia area consisting of Fiji, Rotuma, Tonga, 'Uvea, Futuna and Samoa (Figure 1.1). Within this area, interaction in the past 1000 years appears to have been relatively common. Warfare involving Tongan arrivals is noted in the traditional histories of these islands and is supported by significant linguistic, traditional and archaeological data (e.g. Burrows 1937; Krämer 1995; Sand 1993; Schmidt 2000). From a Tongan perspective, warfare in traditional and historical records has a punctuated expression, with internal and external conflict strongly correlated (i.e. Ross 1985). The most recent conflict phase in the late eighteenth-nineteenth centuries involved polity fragmentation, significant warfare and the construction of fortifications throughout the Tongan archipelago. External conflicts included Tongan involvement in 'wars' in Fiji (Martin 1991), culminating in the Tongan chief Ma'afu's control of east and northern Fiji 
before the archipelago became a British crown colony in 1874 CE (Spurway 2015). An earlier phase of warfare occurred in Tonga c. 1450-1500 CE, when the Tu'i Tonga Takalaua was murdered by two chiefs from a neighbouring chiefdom (Parton et al. this volume). Oral traditions record that Takalaua's son, Kau'ulufonuafekai, then undertook a vigorous military campaign involving fortifications, which subdued dissent within Tonga (Tongatapu, 'Eua, Ha'apai, Vava 'u, Niuatoputapu, Niuafo'ou) and abroad to Samoa, 'Uvea and Futuna (Gifford 1929:54-56; Statham 2013:29-30).

We do not suggest that all conflict in Fiji-West Polynesia can be condensed into two time periods, but note that in two instances instability in the centralised system of Tonga led to major civil conflicts that had significant external impacts including warfare and the construction and use of fortifications. The role of the LIA in these conflicts requires island-specific high-resolution climate records and an emphasis on the archaeological investigation of defensive sites, yet neither traditional history nor ethnohistory currently suggest that climate change was a decisive factor in outbreaks of conflict. In Aotearoa/New Zealand and Fiji, where most Pacific fortifications were made, there are interesting parallels in their defensive sites and features such as proximity to intensively gardened arable land, indications of significant population growth, high rates of internal migration and, in the protohistoric era at least, an increase in the density and size variation of fortifications indicating larger political units and confederations (Anderson this volume; Parry 1997).

The impetus for these defensive configurations is likely a response to external threats (Best 1984:658; Irwin 1985; Parry 1977), especially from inter-regional conflict and migration. It is worth noting that during the LIA — a proposed period of climatic and societal stresspopulations appear to have increased in both subtropical and tropical islands, and complex societies, which arguably reached the level of archaic states, emerged in Tonga, Hawai' $i$, Tahiti and perhaps Pohnpei. Population agglomeration, whether from making war, defending against it or migrating from it, can stimulate the formation of new sociopolitical systems with high levels of social cohesion.

\section{Conclusion}

Carneiro (1970) theorised that the development of complex societies, leading to early states, involved inter-group warfare for limited agricultural land, and archaeological findings support the view that coercion and warfare were involved in state formation (e.g. Clark et al. 2017; Marcus 1998; Spencer 2003; Stanish and Levine 2011). However, the archaeological identification of violence does not tell us whether these seminal conflicts were over arable land. Cyclical theories of conflict in human history suggest that warfare was involved in the expansion and collapse of several societies, implying that conflict is an entrenched and almost inescapable aspect of human history, as in Allison's (2015) 'Thucydides trap', where rising and ruling powers battle for primacy. As rates of violent death in the second millennium CE are now held to be lower than they were in the past, it has been argued that warfare is essentially responsible for the development of large populations ruled by stable governments: that stamping out internal violence creates the conditions for mass economic prosperity (Morris 2014). To return to the quote by Samuel Johnson, violence and conflict may, under certain lights, be conceived as a 'good thing', but this counterintuitive reframing of violence only emphasises how little we know about its deployment and societal influence in the past, particularly in relation to the formation of complex societies. In addition, because many conflicts have a punctuated expression, it may be the case that while larger political entities tend to have an overall lower frequency of warfare, when outbreaks of violence occur, they can result in greater social disruption and a larger number of overall deaths. 
In Australia and the Pacific, the construction of detailed chronological records of aggression is an important research issue, but to develop a better understanding of conflict requires, among other things, detailed climate-environment sequences and the investigation of group sociopolitical structure and interactions. Environmental shortfalls and resource scarcity play a part in conflict, yet so too do the social and political structures of human groups, which while difficult to identify archaeologically are central to understanding variation in the frequency and scale of aggression. Thomas Hobbes and Jean-Jacques Rousseau had contrasting and influential views about human nature and violence in the past, but their ideas were simply thought experiments about human behaviour that can now be tested against increasingly detailed sets of archaeological and environmental data. In 1932, Freud exchanged pessimistic views with Einstein on how conflict seemed innate to human nature:

In some happy corners of the earth, they say, where nature brings forth abundantly whatever man desires, there flourish races whose lives go gently by: unknowing of aggression or constraint. This I can hardly credit; I would like further details about these happy folk. (Freud in Isaacson 2008:597)

It is a truism that is not always appreciated in archaeology that the resources available to every society are 'limited' and therefore that resource shortfalls in the past must be a primary driver of conflict. Yet the frequency and scale of violence varies significantly among contemporary groups located in comparable subsistence environments and which share a similar technology, population number, density and social hierarchy (Knauft and Shankman 1992; Nolan 2003:28; Robarchek and Robarchek 1992). The manner in which different leadership, belief and social systems incentivise competition and inter-group violence are also aspects that need archaeological consideration, particularly in areas where conflict appears to have been endemic (Knauft 1990).

In parts of Fiji, warfare was used to subjugate villages that were then incorporated into unstable regional polities to provide the subsistence and material goods for higher ranked settlements (Clunie 2003; Parry 1977). Ranked villages also existed in Palau and may be manifested in the dense $p \bar{a}$ landscapes of New Zealand (e.g. Irwin 1985; Liston this volume). It was not land per se that was sought in these conflicts, but the ability to control human labour and productivity that materialised chiefly and community power-this may well be the principal driver of endemic internal/territorial conflict. A great advantage of our region is the presence of rich ethnographic and historic records that can be integrated with archaeological data to examine culture contact and colonialism in different landscapes (e.g. Barker et al. 2020; Bedford this volume; May et al. 2017). As we have noted, European culture contact has likely had a significant impact on the scale and intensity of some conflicts. This needs to be taken into account by researchers, but does not necessarily lessen the value of textual records for understanding indigenous conflict, and of course, such material is critical for tracking the complicated and long-term impacts of contact, colonialism and globalisation. We have also identified that societal instability and outbreaks of conflict, both internal and external, were often an outcome of ongoing culture contact and migration (Anderson this volume; Bamforth 1994), which are aspects of human life with a deep past. Globalisation in the relatively recent era was accompanied by the spread of pathogens that contributed to social instability and high rates of violence and conflict that led to millions of deaths (e.g. Tavares et al. 2019).

Historical records and comparative analyses of conflict and warfare including traditional perspectives are an important but often underutilised resource to understand violence in the archaeological record, whether at a single site or in records that extend across landscapes and encompass long periods. Finally, studies of traditional weapons, art, vocabulary and performances, along with an examination of the defensive properties of sites (Reepmeyer et al. this volume) are needed to establish the social dimensions and traditional practices of conflict in our region. 


\section{References}

Allen, M.W. 2014. Hunter-gatherer violence and warfare in Australia. In M.W. Allen and T.L. Jones (eds), Violence and warfare among hunter-gatherers, pp. 97-111. Left Coast Press, California. doi.org/ 10.4324/9781315415970-5.

Allison, G. 2015. The Thucydides trap. Are the U.S. and China headed for war? The Atlantic, 24 September.

Al-Muqdadi, S.W.H. 2019. Developing strategy for water conflict management and transformation at Euphrates-Tigris Basin. Water 11:2037. doi.org/10.3390/w11102037.

Ambrose, W. 1988. An early bronze artifact from Papua New Guinea. Antiquity 62:483-491. doi.org/ $10.1017 / \mathrm{s} 0003598 \times 00074585$.

Amhurst, Lord and B. Thomson 1901. The discovery of the Solomon Islands by Alvaro de Mendana in 1568. Translated from the original Spanish manuscripts. 2 volumes. The Hakluyt Society, London.

Anderson, A.J. 2000. Slow boats from China: Issues in the prehistory of Indo-Pacific seafaring. In S. O'Connor and P. Veth (eds), East of Wallace's Line: Studies of past and present maritime cultures of the Indo-Pacific region, pp. 13-50. Balkema, Rotterdam.

Arrian and A. de Sélincourt 1976. The campaigns of Alexander. Penguin Classics, Hammondsworth and Baltimore.

Ayres, W. (ed.) 1995. Geiseler's Easter Island report: An 1880s anthropological account. Asian and Pacific Archaeology Series No. 12. University of Hawai'i Press, Honolulu.

Bahn, P. 2015. The end of the moai-did they fall or were they pushed? In N. Cauwe and M. De Dapper (eds), Easter Island: Collapse or transformation? A state of the art, pp. 135-152. Royal Academy for Overseas Sciences and Royal Museums of Art and History, Brussels.

Ballara, A. 1976. The role of warfare in Maori society in the early contact period. Journal of the Polynesian Society 85(4):487-506.

Bamforth, D.B. 1994. Indigenous people, Indigenous violence: Precontact warfare on the north American Great Plains. Man 29(1):95-115. doi.org/10.2307/2803512.

Barber, I. 2012. Gardens of Rongo: Applying cross-field anthropology to explain contact violence in New Zealand. Current Anthropology 53: 799-808. doi.org/10.1086/667834.

Barker, B., L.A. Wallis, H. Burke, N. Cole, K. Lowe et al. 2020. The archaeology of the 'Secret War': The material evidence of conflict on the Queensland frontier, 1849-1901. Queensland Archaeological Research 23:25-41. doi.org/10.25120/qar.23.2020.3720.

Beaglehole, J.C. (ed.) 1968. The journals of Captain James Cook on his voyages of discovery. Volume I: The voyage of the Endeavour, 1768-1771. The Hakluyt Society, Cambridge.

Beaglehole, J.C. (ed.) 1969. The journals of Captain James Cook on his voyages of discovery. Volume II: The voyage of the Resolution and Adventure, 1772-1775. The Hakluyt Society, Cambridge. doi.org/ $10.4324 / 9781315086156$.

Bedford, S., D. Haskell-Crook, M. Spriggs and R. Shing. 2020. Encounters with stone: Missionary battles with idols in the southern New Hebrides. Journal of Pacific Archaeology 11(2):21-33.

Best, S. 1984. Lakeba: The prehistory of a Fijian Island. Unpublished PhD thesis. University of Auckland, Auckland.

Best, S. 1993. At the halls of the mountain kings. Fijian and Samoan fortifications: Comparison and analysis. Journal of the Polynesian Society 102(4):385-447. 
Betz, D. 2019. Citadels and marching forts: How non-technological drivers are pointing future warfare towards techniques from the past. Scandinavian Journal of Military Studies 2(1):30-41. doi.org/ $10.31374 /$ sjms.25.

Blick, J.P. 1988. Genocidal warfare in tribal societies as a result of European-induced culture conflict. Royal Anthropological Institute of Great Britain and Ireland 23(4):654-670. doi.org/10.2307/2802598.

Bocquentin, F. and O. Bar-Yosef 2004. Early Natufian remains: Evidence for physical conflict from Mt. Carmel, Israel. Journal of Human Evolution 47:19-23. doi.org/10.1016/j.jhevol.2004.05.003.

Brooks, C.C. 1981. A contribution to the geoarchaeology of Truk, Micronesia. Asian Perspectives 24(1):27-42.

Brown, P. 1989. Coobool Creek: A morphological and metrical analysis of the crania, mandibles and dentitions of a prehistoric Australian human population. Terra Australis 13. Research School of Pacific Studies, The Australian National University, Canberra.

Buckley, B.B., K.J. Anchukaitis, D. Penny, R. Fletcher, E.R. Cook et al. 2010. Climate as a contributing factor in the demise of Angkor, Cambodia. Proceedings of the National Academy of Sciences USA 107(15):6748-6752. doi.org/10.1073/pnas.0910827107.

Buckley, H.R. 2000. A possible fatal wounding in the prehistoric Pacific Islands. International Journal of Osteoarchaeology 10(2):135-141. doi.org/10.1002/(SICI) 1099-1212(200003/04)10:2<135::AIDOA518>3.0.CO;2-O.

Burke, H. and L.A. Wallis 2019. Frontier conflict and the Native Mounted Police in Queensland Database. doi.org/10.25957/5d9fb541294d5.

Burley, D.V., T. Freeland and J. Balenaivalu 2016. Nineteenth-century conflict and the Koivuanabuli fortification complex on Mali Island, Northern Fiji. Journal of Island and Coastal Archaeology 11(1):107-121. doi.org/10.1080/15564894.2015.1050132.

Burney, J. 1813 [1967]. A chronological history of voyages and discoveries in the South Seas. Part 3: From the Year 1620, to the Year 1688. Da Capo Press and N. Israel, Amsterdam and New York.

Burrows, E.G. 1936. Ethnology of Futuna. Bernice P. Bishop Museum Bulletin 138. Bishop Museum, Honolulu.

Burrows, E.G. 1937. Ethnology of Uvea (Wallis Island). Bernice P. Bishop Museum Bulletin 145. Bishop Museum, Honolulu.

Caldararo, N. 2015. Beyond zero population: Ethnohistory, archaeology and the Khmer, climate change and the collapse of civilizations. Anthropology 3(2):1000154. doi.org/10.4172/2332-0915.1000154.

Campbell, I.C. 2009. Chiefs, agitators and the navy: The Mau in American Samoa. Journal of Pacific History 44(1):41-60. doi.org/10.1080/00223340902900779.

Carneiro, R.L. 1970. A theory of the origin of the state. Science 169:733-738.

Carneiro, R.L. 1988. The Circumscription Theory. Challenge and response. American Behavioral Scientist 31(4):497-511. doi.org/10.1177/000276488031004010.

Carson, M.T. 2017. Cultural spaces inside and outside caves: A study in Guam, western Micronesia. Antiquity 91(356):421-441. doi.org/10.15184/aqy.2016.233.

Chappell, D.A. 1993. Frontier ethnogenesis: The case of New Caledonia. Journal of World History $4(2): 307-324$. 
Chippindale, C., B. Smith and P.S.C. Taçon 2000. Visions of Dynamic power: Archaic rock-paintings, altered states of consciousness and 'Clever Men' in Western Arnhem Land (NT), Australia. Cambridge Archaeological Journal 10(1):63-101. doi.org/10.1017/s0959774300000032.

Churchill, W. 1911. The Polynesian wanderings; tracks of the migration deduced from an examination of the proto-Samoan content of Efaté and other languages of Melanesia. The Carnegie Institution of Washington, Washington.

Clark, G. 2005. A 3000-year culture sequence from Palau, western Micronesia. Asian Perspectives 44:349-380. doi.org/10.1353/asi.2005.0020.

Clark, G. 2016. Chiefly tombs, lineage history, and the ancient Tongan state. Journal of Island and Coastal Archaeology 11(3):326-343. doi.org/10.1080/15564894.2015.1098754.

Clark, G. 2017. Violence and early maritime encounters in the Pacific. In C. Beaule (ed.), Frontiers of colonialism, pp. 208-235. University of Florida Press, Florida. doi.org/10.2307/j.ctvx06wxq.15.

Clark, G. and A. de Biran 2010. Geophysical and archaeological investigation of the survivor-camp of the Antelope (1783) in the Palau Islands, Western Pacific. International Journal of Nautical Archaeology 39(2):345-356. doi.org/10.2307/j.ctvx06wxq.15.

Clark, G. and M. Langley 2020. Ancient tattooing in Polynesia. Journal of Island and Coastal Archaeology 15(3):407-420. doi.org/10.1080/15564894.2018.1561558.

Clark, G., C. Reepmeyer, N. Melekiola, J. Woodhead, W.R. Dickinson and H. Martinsson-Wallin 2014. Stone tools from the ancient Tongan state reveal prehistoric interaction centres in the Central Pacific. Proceedings of the National Academy of Sciences USA 111(29):10491-10496. doi.org/10.1073/pnas. 1406165111 .

Clark, G., P. Parton, C. Reepmeyer, N. Melekiola and D. Burley 2017. Conflict and state development in ancient Tonga: The Lapaha earth fort. Journal of Island and Coastal Archaeology 13(3):405-419. doi.org/10.1080/15564894.2017.1337658.

Clarke, P. 2000. Food security and war in Afghanistan. Development 43(3):113-119.

Clarkson, C., Z. Jacobs, B. Marwick, R. Fullagar, L. Wallis et al. 2017. Human occupation of northern Australia by 65,000 years ago. Nature 547:306-310. doi.org/10.1038/nature22968.

Clausewitz, C.V. 1984. On war. Princeton University Press, Princeton.

Clunie, F. 2003. Fijian weapons and warfare. Bulletin of the Fiji Museum No. 2. The Fiji Museum, Suva.

Codrington, R.H. 1901. The Melanesians: Studies in their anthropology and folklore. Clarendon Press, Oxford.

Connor, J. 2002. The Australian frontier wars, 1788-1838. University of New South Wales Press, Sydney.

Cork, E. 2005. Peaceful Harappans? Reviewing the evidence for the absence of warfare in the Indus Civilization of north-west India and Pakistan (c. 2500-1900 BC). Antiquity 79:411-423. doi.org/ $10.1017 /$ s0003598x0011419x.

Crosby, A.W. 1986. Ecological imperialism: The biological expansion of Europe, 900-1900. Cambridge University Press, Cambridge, New York and Melbourne.

Cummins, H.G. 1977. Holy war: Peter Dillon and the 1837 massacres in Tonga. Journal of Pacific History 12(1):25-39. doi.org/10.1080/00223347708572311.

Curr, E.M. 1883. Recollections of squatting in Victoria, then called the Port Phillip District (from 1841 to 1851). George Robertson, Melbourne, Sydney and Adelaide. 
Daly, M. 2012. The Bible and the sword: John Thomas and the Tongan civil war of 1837 . Wesley and Methodist Studies 4:71-90.

D’Arcy, P. 2000. Maori and muskets from a pan-Polynesian perspective. New Zealand Journal of History 34(1):117-132.

Davidson, J.M. 1974. Samoan structural remains and settlement patterns. In R.C. Green and J.M. Davidson (eds), Archaeology in Western Samoa, Volume II, pp. 225-243. Bulletin of the Auckland Institute and Museum Number 7, Auckland.

DeGusta, D. 1999. Fijian cannibalism: Osteological evidence from Navatu. American Journal of Physical Anthropology 110:215-241. doi.org/10.1002/(sici)1096-8644(199910)110:2<215::aidajpa7>3.0.co;2-d.

Dening, G. 1978. Institutions of violence in the Marquesas. In N. Gunson (ed.), The changing Pacific. Essays in honour of H.E. Maude, pp. 134-141. Oxford University Press, Melbourne.

Derrick, R.A. 1974. A History of Fiji. Volume One. Government Press, Suva.

Diamond, J. 2005. Collapse: How societies choose to fail or survive. Penguin Group, Victoria.

Di Cosmo, N., A. Hessl, C. Leland, O. Byambasuren, H. Tian et al. 2018. Environmental stress and steppe nomads: Re-thinking the history of the Uyghur empire (744-840) with paleoclimate data. Journal of Interdisciplinary History 48(4):439-463. doi.org/10.1162/jinh_a_01194.

Dillon, P. 1829. Narrative and successful result of a voyage in the South Seas, performed by order of the Government of British India to ascertain the actual fate of La Pérouse's expedition. Volume II. Hurst, Chance, and Co., London.

DiNapoli, R.J., C.P. Lipo, T. Brosnan, T.L. Hunt, S. Hixon et al. 2019. Rapa Nui (Easter Island) monument (ahu) locations explained by freshwater sources. PLoS ONE 14(1):e0210409. doi.org/ 10.1371/journal.pone.0210409.

DiNapoli, R., C. Lipo and T. Hunt 2020. Revisiting warfare, monument destruction, and the 'Huri Moaiâ' phase in Rapa Nui (Easter Island) culture history. Journal of Pacific Archaeology 12(1):1-24. Available at: pacificarchaeology.org/index.php/journal/article/view/313.

Dittmar, J.M., E. Berger, X. Zhan, R. Mao, H. Wang and H.-Y. Yeh 2019. Skeletal evidence for violent trauma from the bronze age Qijia culture (2,300-1,500 BCE), Gansu Province, China. International Journal of Paleopathology 27:66-79. doi.org/10.1016/j.ijpp.2019.08.002.

Douglas, B. 1980. Conflicts and alliance in a colonial context: Case studies in New Caledonia 1853-1870. Journal of Pacific History 15(1):21-51. doi.org/10.1080/00223348008572386.

Dubois, M.-J. 1970. Les grands refuges de guerre de Hnaened à Maré, Nouvelle-Calédonie. Journal de la Société des Océanistes 26:55-60. doi.org/10.3406/jso.1970.2284.

Dye, T. 2014. Wealth in old Hawai' $i$ : Good-year economics and the rise of pristine states. Archaeology in Oceania 49(2):59-72. doi.org/10.1002/arco.5034.

Earle, T. 1997. How chiefs come to power: The political economy in prehistory. Stanford University Press, Stanford.

Ella, S. 1899. The war of Tonga and Samoa and the origin of the name Malietoa. Journal of the Polynesian Society 8(4):231-234.

Ellis, W. 1844. The history of the London Missionary Society. Volume I. John Snow, London.

Ember, C.R. and M. Ember 1992. Resource unpredictability, mistrust, and war: A cross cultural study. Journal of Conflict Resolution 36:242-262. doi.org/10.1177/0022002792036002002. 
Evans, R. and W. Thorpe 1992. Power, punishment and penal labour: Convict workers and Moreton Bay. Australian Historical Studies 98(25):90-111. doi.org/10.1080/10314619208595895.

Eyre, E.J. 1984. Autobiographical narrative of residence and exploration in Australia 1832-1839. Calaban Books, London.

Feinberg, R. 1998. Oral traditions of Anuta: A Polynesian outlier in the Solomon Islands. Oxford University Press, New York and Oxford.

Fibiger, L., T. Ahlström, P. Bennike and R.J. Schulting 2013. Patterns of violence-related skull trauma in Neolithic southern Scandinavia. American Journal of Physical Anthropology 150:190-202. doi.org/ 10.1002/ajpa.22192.

Field, J.S. 2004. Environmental and climatic considerations: A hypothesis for conflict and the emergence of social complexity in Fijian prehistory. Journal of Anthropological Archaeology 23:79-99. doi.org/ 10.1016/j.jaa.2003.12.004.

Field, J.S. and P.V. Lape 2010. Paleoclimates and the emergence of fortifications in the tropical Pacific Islands. Journal of Anthropological Archaeology 29:113-124. doi.org/10.1016/j.jaa.2009.11.001.

Filihia, M. 1999. Rituals of sacrifice in early post-European contact Tonga and Tahiti. Journal of the Polynesian Society 34(1):5-22. doi.org/10.1080/00223349908572888.

Flas, D. 2015. The mata'a and the 'Collapse Hypothesis'. In N. Cauwe and M. De Dapper (eds), Easter Island: Collapse or transformation? A state of the art, pp. 59-75. Royal Academy for Overseas Sciences and Royal Museums of Art and History, Brussels.

Forster, J.R. 1982. The Resolution journal of Reinhold Forster 1772-1775. Volume III. Edited by M.E. Hoare. The Hakluyt Society, London.

Fowles, J. 1974. On chronocentrism. Futures 6(1):65-68.

Frederickson, C., M. Spriggs and W. Ambrose 1993. Pamwak rockshelter: A Pleistocene site on Manus Island, Papua New Guinea. In M.A. Smith, M. Spriggs and B. Fankhauser (eds), Sahul in review, pp. 144-154. Occasional Papers in Prehistory 24. Department of Prehistory, The Australian National University, Canberra.

Frimigacci, D. and C. Sand 2016. Archéologie de 'Uvea Mama'o. Institut d'archéologie de la NouvelleCalédonie et du Pacifique, Nouméa, Nouvelle Calédonie.

Fry, D. 2006. The human potential for peace: An anthropological challenge to assumptions about war and violence. Oxford University Press, Oxford.

Fujita, M., S. Yamasaki, C. Katagiri, I. Oshiro, K. Sano et al. 2016. Advanced maritime adaptation in the western Pacific coastal region extends back to 35,000-30,000 years before present. Proceedings of the National Academy of Sciences USA 113(40):11184-11189. doi.org/10.1073/pnas.1607857113.

Fullagar, R., J. McDonald, J. Field and D. Donlon 2009. Deadly weapons: Backed microliths from Narrabeen, New South Wales. In M. Haslam, G. Robertson, A. Crowther, S. Nugent and L. Kirkwood (eds), Archaeological science under a microscope: Studies in residue and ancient DNA analysis in Honour of Thomas H. Loy, pp. 258-270. ANU E Press, Canberra. doi.org/10.22459/ta30.07.2009.19.

Gapps, S. 2018. Contested waterways: Aboriginal resistance in early colonial Sydney. Signals 123:22-27.

Gat, A. 2015. Proving communal warfare among hunter-gatherers: The quasi-Rousseauan error. Evolutionary Anthropology 24:111-126. doi.org/10.1002/evan.21446.

Gifford, E.W. 1929. Tongan society. Bernice P. Bishop Museum Bulletin 61. Bernice P. Bishop Museum, Honolulu. 
Gilchrist, R. 2003. Towards a social archaeology of warfare. World Archaeology 35(1):1-6.

Green, R. 1967. Fortifications in other parts of tropical Polynesia. New Zealand Archaeological Association Newsletter 10:96-113.

Green, R.C. 1979. Lapita. In J. Jennings (ed.), The prehistory of Polynesia, pp. 27-60. Australian National University Press, Canberra.

Grguric, N.K. 2008. Fortified homesteads: The architecture of fear in frontier South Australia and the Northern Territory, ca. 1847-1885. Journal of Conflict Archaeology 4(1-2):59-85. doi.org/10.1163/ 157407808 X382764.

Groube, L.M. 1970. The origin and development of earthwork fortifications in the Pacific. In R.C. Green and M. Kelly (eds), Studies in Oceanic culture history, Volume I, pp. 133-164. Pacific Anthropological Records Number 11. Bernice P. Bishop Museum, Honolulu.

Gunson, N. 1969. Pomare II of Tahiti and Polynesian imperialism. Journal of Pacific History 4:65-82. doi.org/10.1080/00223346908572146.

Haddon, A.C. 1928. The cult of Waiet in the Murray Islands, Torres Strait. Memoirs of the Queensland Museum 9(2):127-135.

Handy, E.S.C. 1923. The native culture in the Marquesas. Volume 9: Bayard Dominick expedition. Bernice P. Bishop Museum, Honolulu.

Hanlon, D. 1988. Upon a stone altar: A history of the island of Pohnpei to 1890. University of Hawai' $\mathrm{i}$ Press, Honolulu. doi.org/10.2307/j.ctvp2n4g9.

Harrison, R. 2002a. Archaeology and the colonial encounter: Kimberley spear points, cultural identity and masculinity in the north of Australia. Journal of Social Archaeology 2(3):352-377. doi.org/ $10.1177 / 146960530200200304$.

Harrison, R. 2002b. Australia's iron age: Aboriginal post-contact metal artefacts from old Lamboo Station, Southeast Kimberley, Western Australia. Australasian Historical Archaeology 20:67-76.

Haug, G.H., D. Günther, L.C. Peterson, D.M. Sigman, K.A. Hughen et al. 2003. Climate and the collapse of Maya civilization. Science 299(5613):1731-1735. doi.org/10.1126/science.1080444.

Hill, G.B. and L.F. Powell (eds). 1934. Boswell's life of Johnson. Volume 1. The life (1709-1763). Clarendon Press, Oxford.

Hintze, O. 1975. Military organization and the organization of the state. In F. Gilbert (ed.), The historical essays of Otto Hintze, pp. 179-215. Oxford University Press, New York.

Hitchcock, G. 2017. The final fate of the La Pérouse expedition? The 1818 account of Shaik Jumaul, a Lascar castaway in Torres Strait. The Journal of Pacific History 52(2):217-235. doi.org/10.1080/002 23344.2017.1335370.

Hommon, R.J. 2013. The ancient Hawaiian state: Origins of a political society. Oxford University Press, New York.

Howard, A. and E. Kjellgren 1994. Martyrs, progress and political ambition: Re-examining Rotuma's 'religious wars'. Journal of Pacific History 29(2):131-152. doi.org/10.1080/00223349408572768.

Huang, C.C. and H. Su 2009. Climate change and Zhou relocations in early Chinese history. Journal of Historical Geography 35(2):297-310. doi.org/10.1016/j.jhg.2008.08.006.

Hudjashov, G., P. Endicott, H. Post, N. Nagle, S.Y.D. Ho et al. 2018. Investigating the origins of eastern Polynesians using genome-wide data from the Leeward Society Isles. Scientific Reports 8:1823. doi.org/ 10.1038/s41598-018-20026-8. 
Hutchinson, D.L. 1996. Brief encounters: Tatham mound and evidence for Spanish and native American confrontation. International Journal of Osteoarchaeology 6:51-65. doi.org/10.1002/(sici) 1099-1212 (199601)6:1<51::aid-oa257>3.0.co;2-e.

Igler, D. 2015. Hardly Pacific: Violence and death in the Great Ocean. Pacific Historical Review 84(1):1-18.

Im Thurn, E. and L.C. Wharton (eds) 2010. Journal of William Lockerby, sandalwood trader in the Fijian Islands during the years 1808-1809: With an introduction and other papers connected with the earliest European visitors to the islands. Hakluyt Society, London. doi.org/10.4324/9781315556451.

Irwin, G. 1985. Land, pā and polity. A study based on the Maori fortifications of Pouto. New Zealand Archaeological Association Monograph 15. New Zealand Archaeological Association, Auckland.

Irwin, G., B. Shaw and A. McAlister 2019. The origins of the Kula Ring: Archaeological and maritime perspectives from the southern Massim and Mailu areas of Papua New Guinea. Archaeology in Oceania 54:1-16. doi 10.1002/arco.5167.

Isaac, B. and G. Isaac 2011. Unexpected trajectories: A history of Niuean throwing stones. Journal of the Polynesian Society 120(4):369-401.

Isaacson, W. 2008. Einstein: His life and universe. Pocket Books, London, Sydney, New York, Toronto.

Jones, T., V.A. Levchenko, P.L. King, E. Troitzsch, D. Wesley et al. 2017. Radiocarbon age constraints for a Pleistocene-Holocene transition rock art style: The Northern Running Figures of the East Alligator River region, western Arnhem Land, Australia. Journal of Archaeological Science: Reports 11:80-89. doi.org/10.1016/j.jasrep.2016.11.016.

Kaniewski, D., E. Van Campo, J. Guiot, S. Le Bruel, T. Otto et al. 2013. Environmental roots of the Late Bronze Age crisis. PLoS ONE 8(8):e71004. doi.org/10.1371/journal.pone.0071004.

Keate, G. 1788, An account of the Pelew Islands, situated in the western part of the Pacific Ocean. Composed from the journals and communications of Captain Henry Wilson and some of his officers, who, in August 1783, were there shipwrecked, in the Antelope, a packet belonging to the Honourable East India company. 3rd edition. G. Nichol, London. doi.org/10.5962/bhl.title.160285.

Keeley, L.H. 1996. War before civilization: The myth of the peaceful savage. Oxford University Press, New York.

Keeley, L.H., M. Fontana and R. Quick 2007. Baffles and bastions: The universal features of fortifications. Journal of Archaeological Research 15(1):55-95. doi.org/10.1007/s10814-006-9009-0.

Kennedy, J. and J.E. Brady 1997. Into the netherworld of island earth: A reevaluation of refuge caves in ancient Hawaiian society. Geoarchaeology 12(6):641-655. doi.org/10.1002/(sici)1520-6548 (199709) 12:6<641::aid-gea6>3.0.co;2-z.

Kennett, D.J. and S.B. McClure 2012. The archaeology of Rapan fortifications. In A. Anderson and D.J. Kennett (eds), Taking the high ground. The archaeology of Rapa, a fortified island in remote East Polynesia. ANU E Press, Canberra. doi.org/10.22459/ta37.11.2012.12.

Kimber, R.G. 1990. Hunter-gatherer demography: The recent past in Central Australia. In B. Meehan and N. White (eds), Hunter-gatherer demography, pp. 160-175. University of Sydney, Sydney.

Kirch, P.V. 1984. The evolution of the Polynesian chiefdoms. New Studies in Archaeology. Cambridge University Press, Cambridge.

Kirch, P.V. 2010. How chiefs became kings. Divine kingship and the rise of archaic states in ancient Hawai i University of California Press, Berkeley. doi.org/10.1525/9780520947849.

Kirch, P.V. and R.C. Green 2001. Hawaiki, ancestral Polynesia: An essay in historical anthropology. Cambridge University Press, Cambridge. doi.org/10.1017/cbo9780511613678. 
Kissel, M. and N.C. Kim 2018. The emergence of human warfare: Current perspectives. American Journal of Physical Anthropology 168(S67):141-163. doi.org/10.1002/ajpa.23751.

Kituai, A. 1988. Innovation and intrusion: Villagers and policemen in Papua New Guinea. Journal of Pacific History 23(2):156-166. doi.org/10.1080/00223348808572586.

Knauft, B.M. 1990. Melanesian warfare: A theoretical history. Oceania 60(4):250-311. doi.org/10.1002/ j.1834-4461.1990.tb01557.x.

Knauft, B.M. and P. Shankman 1992. Warfare, Western intrusion and ecology in Melanesia. Comments by Knauft and Shankman. Man 27(2):399-403.

Knuckey, G. 1992. Patterns of fracture upon Aboriginal crania from the recent past. In N.W. Bruce (ed.), Living with civilisation, pp. 47-58. Proceedings of the Australasian Society for Human Biology 5. Centre for Human Biology, University of Western Australia, Perth.

Kolb, M.J. 2006. The origins of monumental architecture in ancient Hawai i. Current Anthropology 47(4):657-665. doi.org/10.1086/506285.

Kolb, M.J. and B. Dixon 2002. Landscapes of war: Rules and conventions of conflict in ancient Hawai $\mathrm{i}$ (and elsewhere). American Antiquity 67(3):514-534. doi.org/10.2307/1593824.

Krämer, A. 1995. The Samoa Islands. Volume II: Material Culture. Translated by Dr Theodore Verhaaren. University of Hawai'i Press, Honolulu.

Kwai, A.A. 2017. Solomon Islanders in World War II: An Indigenous perspective. State, Society and Governance in Melanesia Series. ANU Press, Canberra. doi.org/10.22459/siwwii.12.2017.

Kyle, B., J.S. Field and M. Kenyhercz 2009. Post-Lapita health, lifestyle, and mortuary behaviour in Fiji: A brief report. Rapa Nui Journal 23(1):28-39.

Ladefoged, T.N. 1993. Evolutionary process in an oceanic chiefdom. Intergroup aggression and political integration in traditional Roruman society. Unpublished PhD thesis. University of Hawai $\mathrm{i}$, Honolulu.

Layard, J. 1942. Stone men of Malekula. Chatto and Windus, London.

Lévesque, R. 1992. History of Micronesia. A collection of source documents. Volume 1: European discovery. Lévesque Publications, Quebec.

Lilley, I. 2010. Near Oceania. In I. Lilley (ed.), Early human expansion and innovation in the Pacific, pp. 13-45. International Council on Monuments and Sites, Paris.

Lipo, C.P., T.L. Hunt, R. Horneman and V. Bonhomme 2016. Weapons of war? Rapa Nui mata'a morphometric analyses. Antiquity 90(349):172-187. doi.org/10.15184/aqy.2015.189.

Lipson, M., M. Spriggs, F. Valentin, S. Bedford, R. Shing et al. 2020. Three phases of ancient migration shaped the ancestry of human populations in Vanuatu. Current Biology 30(24):P4846-4856.e6. doi.org/10.1016/j.cub.2020.09.035.

Liston, J. and M. Miko 2011. Oral tradition and archaeology: Palau's earth architecture. In J. Liston, G. Clark and D. Alexander (eds), Pacific island heritage: Archaeology, identity \& community, pp. 181-204. Terra Australis 35. ANU E Press, Canberra. doi.org/10.22459/ta35.11.2011.13.

Liston, J. and H.D. Tuggle 2006. The archaeology of warfare: Prehistories of raiding and conquest. In E.N. Arkush and M.W. Allen (eds), The archaeology of warfare: Prehistories of raiding and conquest, pp. 148-183. University of Florida Press, Florida.

Litster, M. and L. Wallis 2011. Looking for the proverbial needle? The archaeology of Australian colonial frontier massacres. Archaeology in Oceania 46(3):105-117. 
Loeb, E.M. 1926. History and traditions of Niue. Bernice P. Bishop Museum Bulletin 32. Bishop Museum, Honolulu.

Luders, D. 1996. Legend and history: Did the Vanuatu-Tonga kava trade cease in A.D. 1447. Journal of the Polynesian Society 105(3):287-310.

Luders, D. 2001. Retoka revisited and Roimata revised. Journal of the Polynesian Society 110(3):110: 247-288.

Macknight, C.C. 1972. Macassans and Aborigines. Oceania (42):283-321. doi.org/10.1002/j.18344461.1972.tb01183.x.

Marcus, J. 1998. The peaks and valleys of ancient states: An extension of the Dynamic Model. In G.M. Feinman and J. Marcus (eds), Archaic states, pp. 59-94. School of American Research Press, Santa Fe.

Markham, C. 2016. The Voyages of Pedro Fernandez de Quirós, 1595 to 1606. Volumes I-II. Translated and edited by Sir Clements Markham. Routledge, London and New York. doi.org/10.4324/ 9781315551548 .

Martin, J. 1991. Tonga islands: William Mariner's account. 5th edition. Vava'u Press, Nuku'alofa.

May, S.K., D. Wesley, J. Goldham, M. Litster and B. Manera 2017. Symbols of power: The firearm paintings of Madjedbebe (Malakunanja II). International Journal of Historical Archaeology 21:690707. doi.org/10.1007/s10761-017-0393-6.

McArthur, N. 1967. Island populations of the Pacific. Australian National University Press, Canberra.

McBryde, I. 1978. Wil-im-ee Moor-ring: Or, where do axes come from? Stone axe distribution and exchange patterns in Victoria. Mankind 11(3):354-382. doi.org/10.1111/j.1835-9310.1978. tb00666.x.

McDonald, J.J., D. Donlon, J.H. Field, R.L.K. Fullagar, J.B. Coltrain et al. 2007. The first archaeological evidence for death by spearing in Australia. Antiquity 81:877-885. doi.org/10.1017/s0003598 x00095971.

McGowan, H., S.K. Marx, P. Moss and A.M. Hammond 2012. Evidence of ENSO mega-drought triggered collapse of prehistoric Aboriginal society in northwest Australia. Geophysical Research Letters 39(22):L22702. doi.org/10.1029/2012gl053916.

McNiven, I. 1998. Enmity and amity: Reconsidering stone-headed club (Gabagaba) procurement and trade in Torres Strait. Oceania 69(2):94-115. doi.org/10.1002/j.1834-4461.1998.tb02697.x.

McNiven, I. 2018. Ritual mutilation of Europeans on the Torres Strait frontier. Journal of Pacific History 53(3):229-251. doi.org/10.1080/00223344.2018.1499007.

Métraux, A. 1940. Ethnology of Easter Island. Bernice P. Bishop Museum Bulletin 160. Bernice P. Bishop Museum, Honolulu.

Meyer, C., C. Lohr, D. Gronenborn and K.W. Alt 2015. The massacre mass grave of SchöneckKilianstädten reveals new insights into collective violence in Early Neolithic Central Europe. Proceedings of the National Academy of Sciences USA 112(36):11217-11222. doi.org/10.1073/pnas.1504365112.

Mirazón Lahr, M., F. Rivera, R.K. Power, A. Munier, B. Copsey et al. 2016. Inter-group violence among early Holocene hunter-gatherers of West Turkana, Kenya. Nature 529:394-398. doi.org/10.1038/ nature 16477.

Mitchell, S. 2000. Guns or barter? Indigenous exchange networks and the mediation of conflict in post-contact western Arnhem Land. In A. Clarke and R. Torrence (eds), The archaeology of differences: Negotiating cross-cultural engagements in Oceania, pp. 187-220. Routledge, London. 
Montenegro, A., R.T. Callaghan and S. Fitzpatrick 2016. Using seafaring simulations and shortest-hop trajectories to model the prehistoric colonization of Oceania. Proceedings of the National Academy of Sciences USA 113(45):12685-12690. doi.org/10.1073/pnas.1612426113.

Morgan, J. 1980. The life and adventures of William Buckley: Thirty-two years a wanderer among the Aborigines of the unexplored country round Port Philip. Australian National University Press, Canberra.

Morris, I. 2014. War! What is it good for? Conflict and the progress of civilization from primates to robots. Farrar, Straus and Giroux, New York.

Morrison, M., A. Della-Sale and D. McNaughton 2019. War capitalism and the expropriation of country: Spatial analysis of Indigenous and settler-colonial entanglements in North Eastern Australia, 1864-1939. International Journal of Historical Archaeology 23:204-234. doi.org/10.1007/s10761018-0463-4.

Moyle, R.M. 1984. The Samoan journals of John Williams 1830 and 1832. Pacific History Series 11. Australian National University Press, Canberra, London, New York.

Mutch, T.D. 1942. The first discovery of Australia with an account of the voyage of the Duyfken' and the career of Captain Willem Jansz. Reprinted from the Journal of the Royal Australian Historical Society, Vol. 28, Part 5. Sydney.

Neich, R. 2007. Tongan figures: From goddesses to missionary trophies to masterpieces. Journal of the Polynesian Society 116:213-278.

Nicole, R. 2010. Disturbing history: Resistance in early colonial Fiji. University of Hawai'i Press, Honolulu.

Nolan, P.D. 2003. Toward an ecological-evolutionary theory of the incidence of warfare in preindustrial societies. Sociological Theory 21(1):18-30. doi.org/10.1111/1467-9558.00172.

Nunn, P.D. 2003. Nature-society interactions in the Pacific Islands. Geografiska Annaler, Series B: Human Geography 85 (4):219-229. doi.org/10.1111/j.0435-3684.2003.00144.x.

Nunn, P.D. 2007a. Climate, environment and society in the Pacific during the last millennium. Elsevier, Amsterdam.

Nunn, P.D. 2007b. The AD1300 event in the Pacific Basin. The Geographical Review 97(1):1-23.

Nunn, P.D. 2007c. Holocene sea-level change and human response in Pacific Islands. Earth and Environmental Science Transactions of the Royal Society of Edinburgh 98:117-125. doi.org/10.1017/ s1755691007000084.

O'Connor, S., A. McWilliam and S. Brockwell (eds) 2020. Forts and fortification in Wallacea. Terra Australis 53. ANU Press, Canberra. doi.org/10.22459/TA53.2020.

O'Driscoll, J. 2017. Hillforts in prehistoric Ireland: A costly display of power? World Archaeology 49(4):506-525. doi.org/10.1080/00438243.2017.1282379.

Oka, R.C., M. Kissel, M. Golitko, S.G. Sheridan, N.C. Kim et al. 2017. Population is the main driver of war group size and conflict casualties. Proceedings of the National Academy of Sciences USA 114:E11101-E11110. doi.org/10.1073/pnas.1713972114.

Orchiston, D.W. and L.C. Horrocks 1975. Contact and conflict: The Rowe massacre in early Protohistoric New Zealand. Historical Studies 16(65):519-538. doi.org/10.1080/10314617508595522.

Owsley, D.W., K.G. Barca, V.E. Simon and G.W. Gill 2016. Evidence for injuries and violent death. In V.H. Stefan and G.W. Gill (eds), Skeletal biology of the ancient Rapanui (Easter Islanders), pp. 222252. Cambridge University Press, Cambridge. doi.org/10.1017/cbo9781139151856.013. 
Pagliaro, J.B., J.F. Garber and T.W. Stanton 2003. Re-evaluating the archaeological signatures of Maya ritual and conflict. In K.M. Brown and T.W. Stanton (eds), Ancient Mesoamerican warfare, pp. 75-89. Walnut Creek, AltaMira.

Pang, B.K. 2003. In the wake of the ruling chiefs: Forest use on the island of Hawai' $i$ during the time of Kamehamea I. Unpublished PhD thesis. University of Hawai i, Honolulu.

Pardoe, C. 2014. Conflict and territoriality in Aboriginal Australia: Evidence from biology and ethnography. In M.W. Allen and T.L. Jones (eds), Violence and warfare among hunter-gatherers, pp. 112-132. Left Coast Press, California. doi.org/10.4324/9781315415970-6.

Parke, E. 2020. The Christian converts who are setting fire to sacred Aboriginal objects. ABC News, 20 September. www.abc.net.au/news/2019-09-20/the-christian-converts-who-are-setting-fire-tosacred-aboriginal/11527402.

Parmentier, R.J. 1987. The sacred remains: Myth, history, and polity in Belau. The University of Chicago Press, Chicago.

Parry, J.T. 1977. Ring-ditch fortifications in the Rewa Delta, Fiji: Air photo interpretation and analysis. Bulletin of the Fiji Museum, No. 3. The Fiji Museum, Suva.

Parry, J.T. 1981. Ring-ditch fortifications II: Ring-ditch fortifications in the Navua Delta, Fiji: Air photo interpretation and analysis. Bulletin of the Fiji Museum, No. 7. The Fiji Museum, Suva.

Parry, J.T. 1997. The north coast of Viti Levu Ba to Ra air photo archaeology and ethnohistory. Bulletin of the Fiji Museum, No. 10. The Fiji Museum, Suva.

Parton, P., G. Clark, C. Reepmeyer and D. Burley 2018. The field of war: LiDAR identification of earthwork defences on Tongatapu Island, Kingdom of Tonga. Journal of Pacific Archaeology 9(1):11-24.

Pascoe, B. 2014. Dark emu: Aboriginal Australia and the birth of agriculture. Scribe publications, Brunswick and London.

Pearson, W.H. 1970. The reception of European voyagers on Polynesian islands, 1568-1797. Journal de la Société des Océanistes 27:121-154. doi.org/10.3406/jso.1970.2151.

Petchey, F., G. Clark, I. Linderman, P. O’Day, J. Southon et al. 2018. Forgotten news: Shellfish isotopic insight into changing sea-level and associated impact on the first settlers of the Mariana Archipelago. Quaternary Geochronology 48:180-194. doi.org/10.1016/j.quageo.2018.10.002.

Pietrusewsky, M., M.T. Douglas, E.E. Cochrane and S. Reinke 2007. Cultural modifications in an adolescent earth-oven interment from Fiji: Sorting out mortuary practice. Journal of Island and Coastal Archaeology 2:44-71. doi.org/10.1080/15564890701228579.

Pigafetta, A. and J.A. Robinson 1906. Magellan's voyage around the world by Antonio Pigafetta: The original text of the Ambrosian MS., with English translation, notes, bibliography, and index, by James Alexander Robertson with portrait, and facsimiles of the original maps and plates. Volumes I and II. Arthur H. Clark, Cleveland.

Price, N. and R. Knecht 2012. Peleliu 1944: The archaeology of a South Pacific D-Day. Journal of Conflict Archaeology 7(1):5-48. doi.org/10.1179/157407812X13245464933786.

Prickett, N. 2016. Fortifications of the New Zealand Wars. New Zealand Department of Conservation Te Papa Atawahi, Wellington.

Quimby, F. 2011. The Hierro commerce: Culture contact, appropriation and colonial entanglement in the Marianas, 1521-1668. Journal of Pacific History 46(1):1-26. doi.org/10.1080/00223344.2011. 573630. 
Rainbird, P. 1996. A place to look up to: A review of Chuukese hilltop enclosures. Journal of the Polynesian Society 105:461-478.

Reanier, R.E. and D.P. Ryan 2003. Mapping the Poike Ditch. In J. Loret and J.T. Tanacredi (eds), Easter Island: Scientific exploration into the world's environmental problems in microcosm, pp. 207-221. Springer, Boston. doi.org/10.1007/978-1-4615-0183-1_14.

Reynolds, H. 1981. The other side of the frontier: Aboriginal resistance to the European invasion of Australia. UNSW Press, Sydney.

Richards, R. 2004. The earliest foreign visitors and their massive depopulation of Rapa-iti from 1824 to 1830. Journal de la Société des Océanistes 118:3-10. doi.org/10.4000/jso.67.

Robarchek, C.A. and C.J. Robarchek 1992. Cultures of war and peace: A comparative study of Waorani and Semai. In J. Silverberg and J.P. Gray (eds), Aggression and peacefulness in humans and other primates, pp. 189-213. Oxford University Press, New York and Oxford.

Robertson, G. 1973. An account of the discovery of Tahiti from the journal of George Robertson Master H.M.S. Dolphin. Folio Press, London.

Ross, M.H. 1985. Internal and external conflict and violence: Cross-cultural evidence and a new analysis. Journal of Conflict Resolution 29:547-579. doi.org/10.1177/0022002785029004001.

Routledge, K. 1919. The mystery of Easter Island. Hazell, Watson and Viney, London.

Rowley, C.D. 1970. The destruction of Aboriginal society. Aboriginal policy and practice-Volume 1. Australian National University Press, Canberra.

Ryan, L. 2010. Settler massacres on the Port Phillip Frontier, 1836-1851. Journal of Australian Studies 34(3): 257-273. doi.org/10.1080/14443058.2010.498091.

Sahlins, M. 1991. The return of the event, again: With reflections on the beginnings of the Great Fijian War of 1843 to 1845 between the Kingdoms of Bau and Rewa. In A. Biersack (ed.), Clio in Oceania, pp. 37-100. Smithsonian Institution Press, Washington.

Salcedo, H.C. 2015. Environmental violence and its consequences. Latin American Perspectives 204(42):19-26.

Sand, C. 1993. A preliminary study of the impact of the Tongan maritime chiefdom on the late prehistoric society of 'Uvea, western Polynesia. In M.W. Graves and R.C. Green (eds), The evolution and organization of prehistoric society in Polynesia, pp. 43-51. New Zealand Archaeological Association Monograph No. 19. New Zealand Archaeological Association, Auckland.

Sand, C. 1996. Structural remains as markers of complex societies in southern Melanesia during prehistory: The case of the monumental forts of Maré Island (New Caledonia). In I.C. Glover and P. Bellwood (eds), Indo-Pacific prehistory: The Chiang Mai papers. Bulletin of the Indo-Pacific Prehistory Association 15:37-44.

Sand, C. 2001. Changes in non-ceramic artefacts during the prehistory of New Caledonia. In G.R. Clark, A.J. Anderson and T. Vunidilo (eds), The archaeology of Lapita dispersal in Oceania, pp. 75-92. Terra Australis 17. Pandanus Press, Canberra.

Sand, C. 2008. Prehistoric maritime empires in the Pacific: Ga asialilil ('Elili) and the establishment of a Tongan colony on 'Uvea (Wallis, Western Polynesia). In A. Di Piazza, E. Pearthree, and C. Sand (eds), At the heart of ancient societies: French contributions to Pacific archaeology, pp. 73-105. Les Cahiers de l'Archeólogiá en Nouvelle-Calédonie Volume 18. Noumea, New Caledonia.

Sand, C. and F. Valentin 1991. First results of the excavation of the burial mound of Petania, Uvea, Western Polynesia. Indo-Pacific Prehistory Association Bulletin 11:236-246. 
Sand, C., F. Valentin and D. Frimigacci 2006. Sépultures à caveau en Polynésie occidentale: Des traditions orales à l'archéologie. Journal de la Société des Océanistes 122-123:13-25. doi.org/10.4000/jso.511.

Schamberger, K. 2017. Difficult history in a local museum: The Lambing Flat riots at Young, New South Wales. Australian Historical Studies 48(3):436-441. doi.org/10.1080/1031461X.2017.1331693.

Scheidel, W. 2017. The great leveler: Violence and the history of inequality from the Stone Age to the twentyfirst century. Princeton University Press, Princeton.

Schmidt, H. 2003. Loanword strata in Rotuman. In H. Andersen (ed.), Language contacts in prehistory: Studies in stratigraphy, pp. 201-240. John Benjamins, Amsterdam and Philadelphia. doi.org/10.1075/ cilt.239.16sch.

Scott, R.M. and H.R. Buckley 2010. Biocultural interpretations of trauma in two prehistoric Pacific Island populations from Papua New Guinea and the Solomon Islands. American Journal of Physical Anthropology 142:509-518. doi.org/10.1002/ajpa.21250.

Scott, R.M. and H.R. Buckley 2014. Exploring prehistoric violence in Tonga: Understanding skeletal trauma from a biocultural perspective. Current Anthropology 55(3):335-347. doi.org/10.1086/ 676477.

Shankman, P. 1991. Culture contact, cultural ecology, and Dani warfare. Man 26(2):299-321. doi.org/ $10.2307 / 2803834$.

Sharp, L. 1952. Steel-axes for Stone Age Australians. Human Organization 11(2):17-22. doi.org/ 10.17730/humo.11.2.a105413403436788.

Shaw, B., J. Field, G.R. Summerhayes, S. Coxe, A.C.F. Coster et al. 2020. Emergence of a Neolithic in highland New Guinea by 5000 to 4000 years ago. Science Advances 6(13):eaay4573/. doi.org/ $10.1126 /$ sciadv.aay4573.

Shell, R.J. 1999. The Marianas population decline: 17th century estimates. Journal of Pacific History 34(3):291-305. doi.org/10.1080/00223349908572914.

Sheppard, P.J., R. Walter and T. Nagaoka 2000. The archaeology of head-hunting in Roviana Lagoon, New Georgia. Journal of the Polynesian Society 109:9-38.

Shineberg, D. 1966. The sandalwood trade in Melanesian economics, 1841-65. The Journal of Pacific History 1:129-146. doi.org/10.1080/00223346608572084.

Sissons, J. 2011. History as sacrifice: The Polynesian iconoclasm. Oceania 81: 302-315. doi.org/10.1002/ j.1834-4461.2011.tb00110.x.

Skoglund, P., C. Posth, K. Sirak, M. Spriggs, F. Valentin et al. 2016. Ancient genomics and the peopling of the Southwest Pacific. Nature 538(7626):510-513. doi.org/10.1038/nature19844.

Smith. C. 1990. The Poike ditch in retrospect. Rapa Nui Journal 4(3):33, 36-37.

Smith, P. 2000. Into the Kimberley: The invasion of the Sturt Creek Basin (Kimberley region), Western Australia) and evidence of Aboriginal resistance. Aboriginal History 24:62-74. doi.org/10.22459/ ah.24.2011.04.

Smith, S.P. 1903. Niue Island, and its people. Journal of the Polynesian Society 12(1):1-21.

Spencer. C.S. 2003. War and early state formation in Oaxaca, Mexico. Proceedings of the National Academy of Sciences USA 100(20):1185-1187.

Spurway, J. 2015. Ma'afu, prince of Tonga, chief of Fiji. The life and times of Fiji's first Tui Lau. ANU Press, Canberra. doi.org/10.22459/MPTCF.02.2015. 
Stanbury, M. and J. Green (eds) 2004. Laperouse and the loss of the Astrolabe and the Boussole (1788): Reports of the 1986 and 1990 investigations of the shipwrecks at Vanikoro, Solomon Islands. The Australian National Centre of Excellence for Maritime Archaeology Special Publication No. 8, Australasian Institute for Maritime Archaeology Special Publication No. 11, Fremantle.

Stanish, C. and A. Levine 2011. War and early state formation in the northern Titicaca basin, Peru. Proceedings of the National Academy of Sciences USA 108(34):1901-13906. doi.org/10.1073/pnas. 1110176108

Statham, N. (ed.) 2013. A history of Tonga. As recorded by Rev. John Thomas. Bible Society in Korea, Seoul.

Stevens, H.N. and G.F. Barwick (eds) 2010. New light on the discovery of Australia as revealed by the journal of Captain Don Diego de Pradoy Tovar. Ashgate Publishing Company, Surray and Burlington. doi.org/10.4324/9781315597997.

Stevenson, C.M. and C. Williams 2018. The temporal occurrence and possible uses of obsidian mata'a on Rapa Nui (Easter Island, Chile). Archaeology in Oceania 53:92-102. doi.org/10.1002/arco.5145.

Suggs, R.C. 1961. The archaeology of Nuku Hiva, Marquesas Islands, French Polynesia. Anthropological Papers of the American Museum of Natural History 49, Part 1. American Museum of Natural History, New York.

Summerhayes, G.R., M. Leavesley, A. Fairburn, H. Mandui, A. Field et al. 2010. Human adaptation and plant use in Highland New Guinea 49,000 to 44,000 years ago. Science 330(6000):78-81. doi.org/ 10.1126/science.1193130.

Sutton, P. 2008. Stories about feeling: Dutch-Australian contact in Cape York Peninsula, 1606-1675. In P. Veth, P. Sutton and M. Neale (eds), Strangers on the shore: Early coastal contacts in Australia, pp. 35-59. National Museum of Australia Press, Canberra.

Taçon, P. and C. Chippindale 1994. Australia’s ancient warriors: Changing depictions in the rock art of Arnhem Land, N.T. Cambridge Archaeological Journal 4:211-248. doi.org/10.1017/s09597743 00001086 .

Tainter, J.A. 2009. The collapse of complex societies. New Studies in Archaeology. Cambridge University Press, Cambridge.

Tau, T.M. and A. Anderson (eds) 2008. Ngäi Tahu: A migration history. The Carrington text. Bridget Williams Books, Wellington.

Tavares, G.M., G. Reales, M.C. Bortolini and N.J.R. Fagundes 2019. Measuring the impact of European colonization on Native American populations in Southern Brazil and Uruguay: Evidence from mtDNA. American Journal of Human Biology 31:e23243. doi.org/10.1002/ajhb.23243.

Tcherkézoff, S. 2003. A long and unfortunate voyage towards the 'invention' of the Melanesia/Polynesia distinction 1595-1832. Journal of Pacific History 38(2):175-196. doi.org/10.1080/0022334032000 120521.

Thivet, D. 2008. Thomas Hobbes: A philosopher of war or peace? British Journal for the History of Philosophy 16(4):701-721. doi.org/10.1080/09608780802407407.

Torrence, R., S. Kelloway and P. White 2013. Stemmed tools, social interaction, and voyaging in earlymid Holocene Papua New Guinea. Journal of Island and Coastal Archaeology 8(2):278-310. doi.org/ 10.1080/15564894.2012.761300.

Turchin, P. 2006. War and peace and war: The rise and fall of empires. PI Press, New York.

Turner, G. 1861. Nineteen years in Polynesia: Missionary life, travels, and researches in the islands of the Pacific. John Snow, London. 
Valentin, F., G. Clark, P. Parton and C. Reepmeyer 2020. Mortuary practices of the first Polynesians: Formative ethnogenesis in the Kingdom of Tonga. Antiquity 94(376):999-1014. doi.org/10.15184/ aqy.2020.89.

Vayda, A.P. 1970. Maori and muskets in New Zealand: Disruption of a war system. Political Science Quarterly 85(4):560-584. doi.org/10.2307/2147596.

Vayda, A.P. 1976. War in ecological perspective: Persistence, change, and adaptive processes in three Oceanian societies. Plenum Press, New York and London. doi.org/10.1007/978-1-4684-2193-4.

Vilar, M.G., C.W. Chan, D.R. Santos, D. Lynch, R. Spathis et al. 2012. The origins and genetic distinctiveness of the Chamorros of the Mariana Islands: An mtDNA perspective. American Journal of Human Biology 25(1):116-122. doi.org/10.1002/ajhb.22349.

Wallis, L.A., N. Cole, H. Burke, B. Barker, K. Lowe et al. 2017. Rewriting the history of the Native Mounted Police in Queensland. Nulungu Insights No. 1. Nulungu Research Institute, The University of Notre Dame, Sydney.

Walter, R., T. Thomas and P. Sheppard 2004. Cult assemblages and ritual practice in Roviana Lagoon, Solomon Islands. World Archaeology 36(1):142-157. doi.org/10.1080/0043824042000192614.

Walth, C.K. (ed.) 2016. Archaeological investigations at the Naton Beach site, Tumon, Guam. Volume II: The osteological analysis of the human remains. SWCA Environmental Consultants, New Mexico.

Webb, S. 1991. The palaeopathology of Aboriginal Australia. Cambridge University Press, Cambridge.

Webster, D. 1998. Warfare and status rivalry: Lowland Maya and Polynesian comparisons. In G.M. Feinman and J. Marcus (eds), Archaic states, pp. 311-351. School of American Research Press, Santa Fe.

Weiner, M. 1971. The Macedonian syndrome: An historical model of international relations and political development. World Politics 23(4):655-683. doi.org/10.2307/2009855.

Weisler, M., R. Bolhar, J. Ma, E. St. Pierre, P. Sheppard et al. 2016. Cook Island artifact geochemistry demonstrates spatial and temporal extent of pre-European interarchipelago voyaging in East Polynesia. Proceedings of the National Academy of Sciences USA 113(29):8150-8155. doi.org/10.1073/pnas. 1608130113.

Wesley, D., T. Jones, S. O’Connor, J. Fenner and W. Dickinson 2014. Earthenware of Malara, Anuru Bay: A reassessment of potsherds from a Macassan trepang processing site, Arnhem Land, Australia, and implications for Macassan trade and the trepang industry. Australian Archaeology 79(1):14-25. doi.org/10.1080/03122417.2014.11682015.

Westaway, M., D. Williams, R. Wright, R. Wood, J. Olley et al. 2016. The death of Kaakutja: A case of peri-mortem weapon trauma in an Aboriginal man from north-western New South Wales, Australia. Antiquity 90(353):1318-1333. doi.org/10.15184/aqy.2016.173.

Wilkes, C. 1985. United States Exploring Expedition. Volume III: Tongataboo, Feejee group, Honolulu. Fiji Museum, Suva.

Williams, A.N., S. Ulm, A.R. Cook, M.C. Langley and M. Collard 2013. Human refugia in Australia during the Last Glacial Maximum and Terminal Pleistocene: A geospatial analysis of the 25-12 ka Australian archaeological record. Journal of Archaeological Science 40:4612-4625. doi.org/10.1016/ j.jas.2013.06.015.

Wilmshurst, J.M., T.L. Hunt, C.P. Lipo and A. Anderson 2011. High-precision radiocarbon dating shows recent and rapid initial human colonization of East Polynesia. Proceedings of the National Academy of Sciences USA 108(5): 1815-1820. doi.org/10.1073/pnas.1015876108. 
Wilson, J. 1799. A missionary voyage to the Southern Pacific Ocean, performed in the years 1796, 1797, 1798 in the ship Duff, commanded by Captain James Wilson. Chapman, London.

Wimmer, A. and B. Min. 2006. From empire to nation-state. Explaining wars in the modern world, 1816-2001. American Sociological Review 71(6):867-897.

Winter, O., G. Clark, A. Anderson and A. Lindahl 2012. Austronesian sailing to the northern Marianas, a comment on Hung et al. (2011). Antiquity 86(333):898-910. doi.org/10.1017/ s0003598x00047992.

Worthy, T.H. and G. Clark 2009. Bird, mammal and reptile remains. In G.R. Clark and A.J. Anderson (eds), The early prehistory of Fiji, pp. 231-258. Terra Australis 31. ANU E Press, Canberra. doi.org/ 10.22459/ta31.12.2009.10.

Wright, D., T. Denham, D. Shine and M. Donohue 2013. An archaeological review of western New Guinea. Journal of World Prehistory 26:25-73. doi.org/10.1007/s10963-013-9063-8.

Yokoyama, Y., T.M. Esat, W.G. Thompson, A.L. Thomas, J.M. Webster et al. 2018. Rapid glaciation and a two-step sea level plunge into the Last Glacial Maximum. Nature 559:603-607. doi.org/10.1038/ s41586-018-0335-4.

York, R. and G. York 2014. Slings and slingstones: The forgotten weapons of Oceania and the Americas. Kent State University, Ohio.

Younger, S.M. 2008. Conditions and mechanisms for peace in precontact Polynesia. Current Anthropology 49:927-934. doi.org/10.1086/591276.

Younger, S.M. 2009. Violence and warfare in the pre-contact Caroline Islands. Journal of the Polynesian Society 118(2):135-164.

Younger, S.M. 2014. Violence and warfare in precontact Melanesia. Journal of Anthropology 2014:658597. doi.org/10.1155/2014/658597.

Yu-Ch'uan, W. 1936. The rise of land tax and the fall of dynasties in Chinese history. Pacific Affairs 9(2):201-220. doi.org/10.2307/2751407.

Zhang, D.D., P. Brecke, H.F. Lee, Y.-Q. He and J. Zhang 2007. Global climate change, war, and population decline in recent human history. Proceedings of the National Academy of Sciences USA 104:19214-19219. doi.org/10.1073/pnas.0703073104. 
This text is taken from Archaeological Perspectives on Conflict and Warfare in Australia and the Pacific, edited by Geoffrey Clark and Mirani Litster, published 2022 by ANU Press, The Australian National University, Canberra, Australia.

doi.org/10.22459/TA54.2021.01 